\title{
Antiviral agents
}

By D.L. Swallow, M.A., B.Sc., D.Phil., F.R.I.C.

Imperial Chemical Industries Limited, Pharmaceuticals Division, Alderley Park, Macclesfield, Cheshire, England

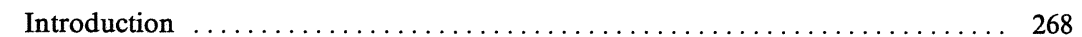

Interferons and interferon inducers $\ldots \ldots \ldots \ldots \ldots \ldots \ldots \ldots \ldots \ldots \ldots \ldots, \ldots \ldots \ldots$

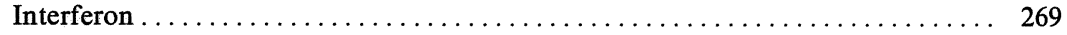

Interferon inducers $\ldots \ldots \ldots \ldots \ldots \ldots \ldots \ldots \ldots \ldots \ldots \ldots \ldots \ldots \ldots \ldots \ldots \ldots \ldots \ldots \ldots \ldots, 270$

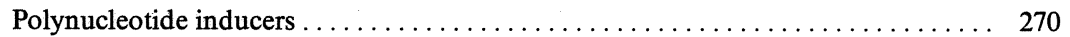

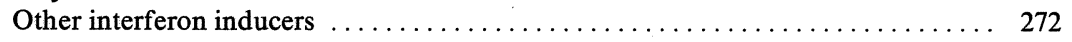

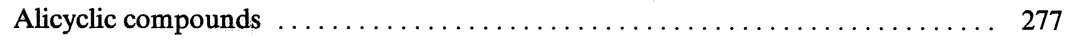

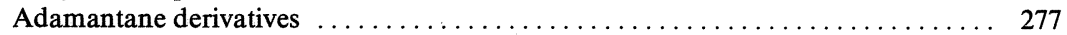

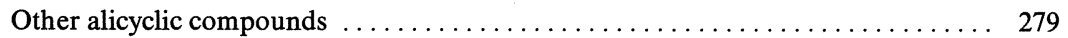

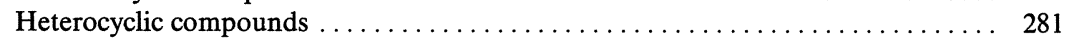

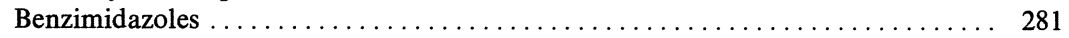

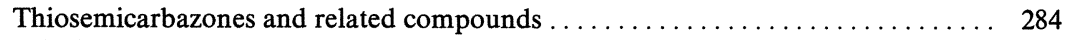

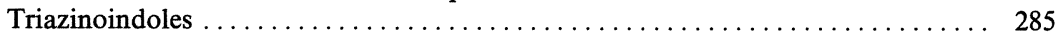

Other heterocyclic antivirals $\ldots \ldots \ldots \ldots \ldots \ldots \ldots \ldots \ldots \ldots \ldots \ldots \ldots \ldots, 286$

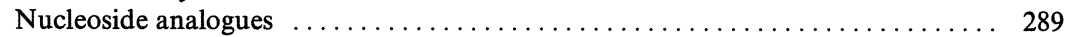

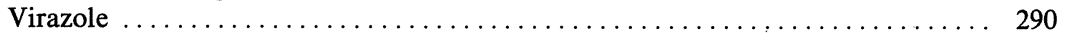

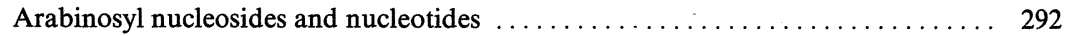

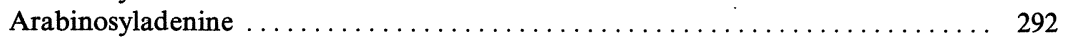

Arabinosylcytosine ...................................... 293

Arabinosylthymine ....................................... 294

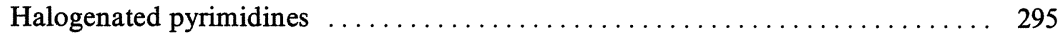

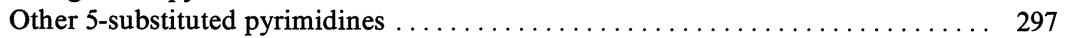

Isoprinosine . . . . . . . . . . . . . . . . . . . . . . . . . . . . . . . . . . 297

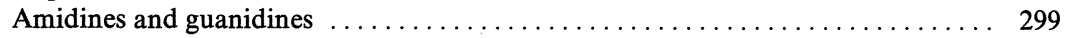

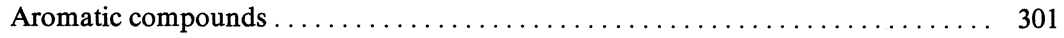

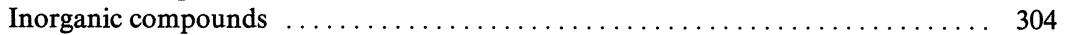

Aliphatic compounds ...................................... 305

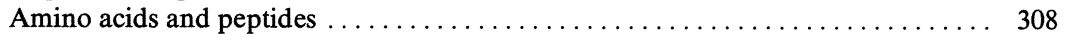

Natural products . . . . . . . . . . . . . . . . . . . . . . . . . . . . . 309

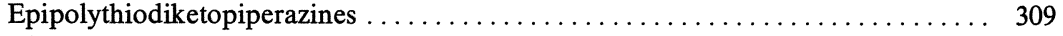

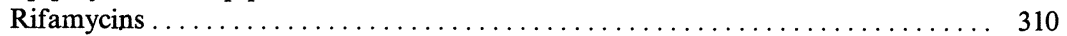

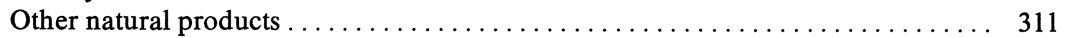

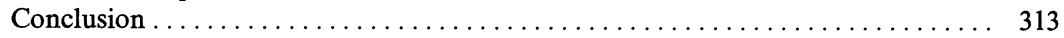

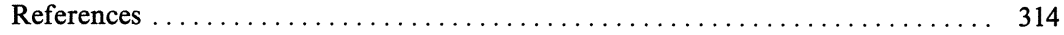


"If only someone could find a cure for flu and colds, what a pleasant place the world would be." How many times in a year does one hear this cry from the heart, when people are in the throes of an upper respiratory virus infection, noses running, coughing, sneezing and feeling utterly miserable.

What a multitude of challenges it presents to the research worker trying to do just that. How do you prevent a virus, which is using your own cellular replicative mechanisms to reproduce itself, from replicating without damage to the cell? Would therapy be any use once symptoms were apparent? Is it ethical to advocate prophylactic treatment within families for a relatively mild self-limiting disease? What is the real cause of all the symptoms and could these be alleviated without having to kill the virus? Could an antiviral drug ever be found which was sufficiently free from toxicity and side effects to be available for everyone's home medicine cabinet?

It is the objective of this review to present some of the advances made during the last seven or eight years in the field of chemotherapy of those human virus diseases which are not adequately controlled or prevented by satisfactory vaccines. While this proviso might seem to narrow the field considerably, it really serves to concentrate it to the major target areas for chemotherapeutic approaches, influenza, common cold, herpes simplex, herpes varicella/zoster, hepatitis, and to a lesser extent adenovirus, cytomegalovirus and viral encephalitis infections. A large amount of research is, of course, devoted to the chemotherapy of viruses which cause cancer in animals with the prospect of finding useful drugs for human cancers, but cancer virus chemotherapy is really a separate topic which has been frequently reviewed [1-3] and I am excluding it from the present review.

I am organizing the review on the basis of the chemical types of compounds for which antiviral activity has been claimed, mainly because many compounds are said to have activities against a wide range of viruses, and would thus have to be mentioned several times in a disease based review. The compounds are grouped into broad chemical classes according to the principal chemical feature of each molecule, except for the first and last sections where a generic title (interferon inducers, natural products) covers a very wide range of structural types. Within each section, compounds of special interest are given sub-headings as are any sub-divisions of the structural types.

Inevitably many of the newly reported compounds have been tested only in tissue or organ culture, or in animal models of the human disease process. Relatively few have shown sufficient promise for clinical trials in human volunteers, and very, very few have survived the selection process to become clinically useful drugs. It must be remembered, though, that we are still in the early years of antiviral chemotherapy, and that it is a very difficult field in which to achieve success. The recent reviews were entitled 'Antiviral Chemotherapy - First Decade' [4] and 'Chemotherapy - Antiviral Agents Come of Age' [5], so although the starting point is in doubt, it is reasonably clear that 
we are still in the 'early' years. Very significant advances have been made during the last 7 years since I last reviewed the subject in detail [6] and these will be highlighted in the text. Standards applied to testing of potential antiviral agents have improved and may more authors are reporting the concentration at which a compound begins to show toxicity in the test system as well as its minimum inhibitory concentration to the virus. This information is essential for proper assessment of a selective antiviral effect, and the more sensitive the method used for determining toxicity the more reliable the work becomes. It does mean, however, that many more hopeful compounds have to be labelled 'inactive', but those that survive have genuine activity and are worth investigating further.

A few papers have been seen recently in which the authors have used what I consider to be the most sensitive of all tests for toxicity of a compound in an in vitro system - growing cells for several days in the continuous presence of various concentrations of the compound. If the compound shows an antiviral effect at concentrations below that at which growth of the cells begins to be impaired, then it really does have a selective antiviral effect.

As new techniques have been developed for isolating, growing and studying viruses, investigating their biochemistry and ways of preventing their replication, so the scientific literature has grown enormously. I have attempted to survey it up to December 1977, using computer-based search techniques in the main, to direct me to the literature on antiviral agents. Reviews of the topic appear more frequently and each year there is a brief but useful update in Annual Reports of Medicinal Chemistry, e.g. [7, 8]. Some reviews cover antiviral agents per se [9-12], while others review the treatment of virus diseases with chemotherapeutic agents [13-19]. Therapy of several specific diseases have been reviewed, herpes infections [20, 21], influenza [22] and arenavirus infections [23], while an overview of the whole field can be obtained from the collected papers presented at the 3rd Conference on Antiviral Substances [24].

\section{Interferon and interferon inducers}

\subsection{Interferon}

This most elusive of natural products and potentially one of the most valuable, still retains many of its secrets. As the prospects of early success in its isolation and purification receded several of the interested pharmaceutical companies withdrew from the field, leaving it to a much smaller group of enthusiasts, whose efforts are now being rewarded with significant advances in our understanding of what interferon is and how it acts in inhibiting virus replication. Reviews on the current status of interferon appear frequently [25-27]. One has special reference to production and purification [28]. It is these two factors which have held up the development of human interferon for human use, production in quantity and purification of the active entity 
from extraneous and possibly harmful proteins and cell components. Industrial scale production requires a human cell line capable of growing indefinitely in large fermenters and, of course, able to produce interferon in response to a virus infection. Gresser and Tovey described such a process in 1974 [29] using a continuous human leucocyte cell line from a case of Burkitt's lymphoma. Their final purified product, concentrated by evaporation at low temperature contained $10^{6}$ units $/ \mathrm{ml}$ of human interferon. Most of the human interferon used in clinical trials has been made in batches from human 'buffy coat' leucocytes isolated from blood and stimulated with parainfluenza virus [30]. Extensive purification and safety testing is required for each batch before use, as with all methods of production, and final titres are in the region of $10^{6}$ units/ml.

What is interferon? The clinical trial material described above was a dilute solution of one or more proteins having the ability to prevent virus infection either in vitro or in vivo. Its biological activity in terms of units is enormous and a $10^{6} \mathrm{unit} / \mathrm{ml}$ solution might only contain $1 \mu \mathrm{g}$ of 'pure' protein per $\mathrm{ml}$. The present estimate is that when eventually a pure sample of interferon is obtained its activity will be $10^{9}$ units $/ \mathrm{mg}$ and it will be a protein, not a glycoprotein. The best sample obtained so far is about $10^{8.5}$ units/mg [31]. The protein from leucocytes differs somewhat from that obtained from fibroblasts, so that human interferon is probably a family of related proteins. Animal interferons are different again. Estimates of molecular weight vary from a minimum of 12,000 to $>100,000$. The complex picture was well reviewed some years ago [32].

The mechanism by which interferon acts has been intensively studied and frequently reviewed, e.g. [33, 34], but the ultimate secrets which might enable man to design a simpler molecule with the same unique properties are still well kept.

Interferon preparations have been used successfully against a variety of virus diseases - herpes zoster [35, 36], rhinovirus [37], herpes keratitis [38], and most recently in a case of Elbola virus infection in which the mortality was $89 \%$ in untreated cases [39]. The main requirement for success is the administration of large amounts of interferon. In the rhinovirus trial a total of $14 \times 10^{6}$ units of interferon was given intranasally divided into 39 doses, while in the Elbola virus case $3 \times 10^{6}$ units were given intramuscularly every 12 hours for 14 days. Early trials, when only relatively small amounts of interferon were available, were never clearly successful. The prospects for clinical use of interferon have been reviewed by Dr. K. Cantell [40] who has pioneered the production and purification of much of the world's supply of human leucocyte interferon.

\subsection{Interferon inducers}

2.21 Polynucleotide inducers

Viruses replicating in animals or in a cell culture induce the formation of interferon within the infected cells, the trigger for this activity being the 
double-stranded replicative form of the viral nucleic acid. Would other double-stranded nucleic acids or analogous molecules do the same? In 1965, Isaacs, the discoverer of interferon, came to the conclusion reluctantly, after several years work, that they would not [41]. Only 2 years later, evidence was published that a recently discovered interferon inducer isolated from Penicillium stoloniferum was not a polysaccharide but a double-stranded RNA [42]. Since then a vast literature on polymeric nucleotides of natural and synthetic origin has been published but the most significant and most studied has been the complementary double-stranded complex of polyinosinic acid and polycytidylic acid [poly (rI:rC)]. For the early studies on this and related compounds the reader is referred to the excellent review by Field [43].

The more recent work on poly (rI:rC), which as prepared and used is usually a random mixture of molecular sizes, has concentrated on improving its stability to nucleases present in serum, modifying its structure chemically, identifying the optimum range of molecular weight for good interferon induction, and investigating its clinical uses.

Although poly (rI:rC) induced high levels of circulating interferon when dosed intravenously to rodents, rabbits and dogs $(0.5-5.0 \mu \mathrm{g} / \mathrm{kg})$, little or none could be detected in primate species. This lack was ascribed to efficient breakdown of the polymer by ribonucleases present in primate serum. Complexing the polymer with basic polymers, e.g. diethylaminoethyldextran, poly-L-lysine or poly-L-arginine improved interferon induction and stability to nucleases. Poly-L-lysine was particularly effective and its complex with poly (rI:rC) has been used to give complete prophylactic control of Simian haemorrhagic fever in monkeys [44] and for prophylaxis and treatment of yellow fever also in monkeys [45]. Further modification by addition of carboxymethyl cellulose to the complex enhanced the stability to primate serum nucleases ten times compared with poly (rI:rC) itself. High levels of circulating interferon were produced in monkeys and chimpanzees with an i.v. dose of $3-5 \mathrm{mg} / \mathrm{kg}$, while a similar dose of poly (rI:rC) gave no detectable interferon. No toxic effects were observed with these doses [46]. This same preparation was finally given human patients suffering from herpes encephalitis and St. Louis encephalitis by i.v. dosage at $0.15-0.3 \mathrm{mg} / \mathrm{kg}$ per day for 5 days. Serum levels of 250-800 units/ml of interferon were produced, being the highest levels ever recorded in man. The treatment produced slight toxic effects but these were transient and the patients recovered from their virus infections [47]. Clinical studies with poly (rI:rC) itself have recently been reported in 15 children suffering from life-threatening neurological disease of probable viral origin [48], while its anti-tumour activity has long been known [43].

Chemical modifications of poly (rI:rC) and its analogues have been numerous but none have shown significant overall advantages. When the 2 '-OH of the ribose moiety in poly $\mathrm{C}$ was methylated and the product complexed with poly I, the product was no longer an interferon inducer, but if 5-methyl poly $\mathrm{C}$ was prepared and complexed with poly I then this product did induce interferon [49]. Replacement of certain oxygens by sulphur gave retention of 
activity, e.g. poly $\mathrm{C}$ replaced by poly (2-thiocytidylic acid) [50], poly $\mathrm{C}$ replaced by poly (6-thioinosinic acid) [51], and thiophosphate instead of phosphate at the $5^{\prime}$-position of the ribose [52]. Certain halogen substitutions retain activity either on the sugar, e.g. $2^{\prime}-\mathrm{Cl}[52]$ or $2^{\prime}-\mathrm{F}$ [53] or in the heterocyclic ring, e.g. 5-bromocytosine or 7-iodo-inosine [54]. Oxidation of poly (rI:rC) with either $\mathrm{H}_{2} \mathrm{O}_{2}$ or peracids gives $\mathrm{N}$-oxides which retain the double-stranded structure and activity of the original complex and are said to be less toxic [55]. Co-polymers of inosinic acid with 2-methythio-inosinic acid or 2-N,Ndimethylguanylic acid are also active [56]. It seems clear that all polynucleotide inducers suffer from the same problem that high interferon inducing activity brings high toxicity [57, 58], although humans and primates are less susceptible to the toxic effects than other animal species due to more efficient detoxification mechanisms.

\subsection{Other interferon inducers}

The number of microorganisms, fungi and fungal products, polymers and low molecular weight compounds which will induce interferon formation in animals, is already large and no doubt will continue to increase. A comprehensive review was written in 1973 by de Clercq [59] and by Metz in 1975 [60]. Although the exact identity of the inducers in whole bacteria or protozoa is not known, endotoxins extracted from many of the species - E.coli, Salmonella species, Brucella abortus for example, are all effective inducers in animals of an interferon with peak blood levels 2-4 hours after administration. Peak blood levels with whole bacteria are in general much later ( $>6 \mathrm{hrs}$ ), but this might only represent the time taken to disrupt the bacteria. Some fungi and fungal extracts have potent interferon inducing activity but it has often taken several years' intensive work to show conclusively that the active entity is not a metabolite of the fungus itself but the replicative double-stranded RNA (ds-RNA) of a virus which is present naturally in the fungus. Statolon, the extract from Penicillium stoloniferum [61, 62], and helenine from Penicillium funiculosum [42], were about the first to be so identified. Penicillium chrysogenum, which is the source of penicillin, also has its virus and ds-RNA [63]. Aspergillus foetidus [64], Stemphylium botryosum [65], Euproctis chrysorrhoea [66] and Cephalosporium acremonium [67] are among many reported sources. Extracts from the Japanese mushrooms Cortinellus shiitake [68] and Lentinus edodes [69] were shown to contain virus particles and ds-RNA, the latter some 8 years after its discovery [70]. Fungal viruses and their ability to induce interferon were reviewed in 1975 by Kleinschmidt and Ellis [71].

The majority of interferon-inducing polymers were investigated in the late 1960's, pyran (divinyl ether-maleic anhydride co-polymer) [72, 73], polyacrylic acid [74] and the polyacetal carboxylic acids derived from oxyamylose, oxyamylopectin and oxycellulose [75]. Their main drawbacks were a lack of biodegradability leading to deposition in the reticuloendothelial system, 
cleaving only after many months, and the high doses required to produce detectable circulating interferon in man. Occasional papers still appear pyran [76], carbopol (polycarboxylate) [77], oxyamylose [78].

Of the low molecular weight, non-polymeric inducers, tilorone hydrochloride (I) is the most studied, being the first to be discovered. It was remarkable in that it was active when dosed orally to mice, whereas all previously discovered inducers had to be dosed parenterally [79].<smiles>CCNCCOc1ccc2c(c1)C(=O)c1cc(OCCN(CC)CC)ccc1-2</smiles>

The development of this discovery by the Richardson-Merrell scientists has produced an impressive number of analogues in which all the sections of the original molecule have been varied. The overall pattern has been to produce molecules in which two nitrogen containing basic centres in the side chains are kept approximately the same distance apart by a variety of flexible linking groups attached to a linear tricyclic nucleus, two or more rings of which are aromatic. The diagram below indicates the majority of the variations made.

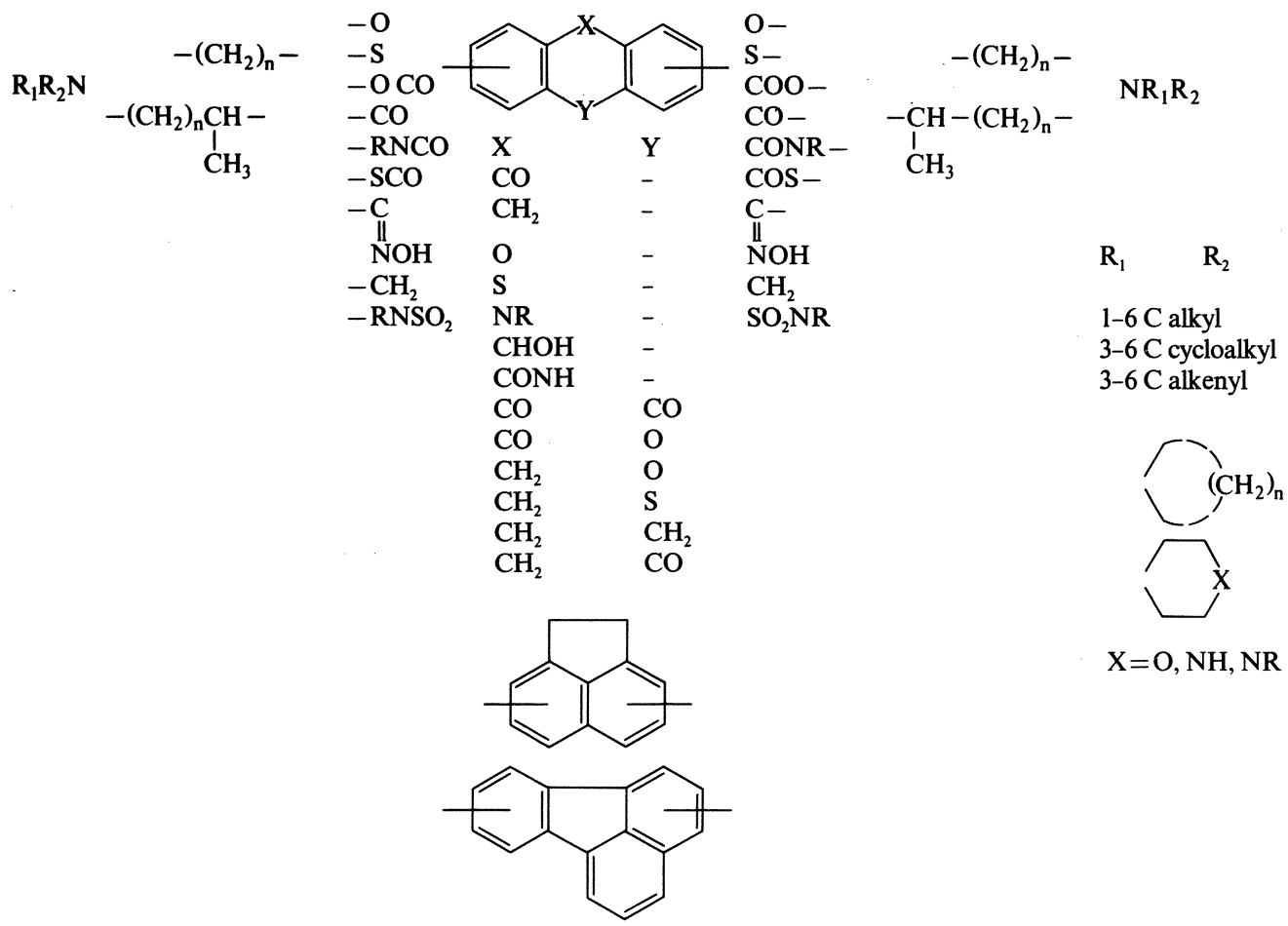


Discussion of structure-activity relationships would require a review in itself and the reader is referred to the series of papers published by the RichardsonMerrell group in which the relationships are fully discussed [80-87]. Tilorone itself remains the most widely tested although several other close analogues, e.g. II, have been selected for thorough pre-clinical evaluation and safety testing.<smiles>CCNCCOc1ccc2c(c1)C(=O)c1ccc(OCCN)cc1C2=O</smiles>

II

The antiviral effects of tilorone have been demonstrated mainly in rodents, in which by oral dosing it is highly effective against a wide variety of RNA and DNA viruses, if given prophylactically [88]. Some of the analogues were shown to be as active as tilorone in mice against Venezuelan equine encephalitis again dosed orally 24 hours before infection. Intraperitoneal dosing was much less effective, while dosing orally 24 hours after infection had no effect on the progress of infection [89]. It will suppress solid tumour growth in rats [90] and will inhibit the activity of RNA-dependent DNA polymerase of tumour viruses in vitro [91]. However, in cautious experiments in humans, oral dosing with amounts up to $4 \mathrm{~g}$ did not produce detectable interferon in the serum [92]. Only slight amelioration of a rubella infection in male volunteers was produced by a single oral dose of $750 \mathrm{mg}$ given 24 hours before infection [93], while an anticancer trial in ten patients with a variety of cancers gave partial responses in only two patients with metastatic melanoma [94]. In this trial it was judged that the maximum tolerated dose was $10 \mathrm{mg} / \mathrm{kg}$ per day. Adverse effects, nausea, vomiting, lethargy, were common but not serious. However, when a tilorone solution $(200 \mathrm{mg} / \mathrm{ml})$ was dropped into the eyes of human volunteers as a potential treatment for ocular herpes at the rate of 1 drop/day for 7 days, a fine layer of solid was deposited in the corneal epithelium first noticed 10 days after therapy began, which caused blurring of vision, and taking 2 months to clear completely [92].

Continuing animal studies are finding further adverse effects, e.g. T-lymphocyte depletion in rats [95], accelerated mortality in young mice [96] and enhancement of endotoxin toxicity [97] and one has to conclude that tilorone and its analogues are fairly toxic compounds with only marginal antiviral activity in human disease.

Despite this, other workers have been anxious to exploit the few structural types not already examined. Austrian workers have prepared the 2,7-diaminofluorenone (III), as well as the related diaminobenzophenones and diaminobiphenyls (IV) [98], and attached acyl side chains ending in basic alkyl amino groups. These are uncomfortably close to the highly carcinogenic 2,7-diacetyl- 
aminofluorene. Pfizer have claimed phenanthridine and phenanthridinone nuclei $[99,100]$, Searle a fluorenone nucleus with the oxyalkyl side chains ending in a variety of aza-polycyclic hydrocarbons [101], and Indian chemists have prepared N- and O-dialkylaminoalkyl carbazoles [102].<smiles>Nc1ccc2c(c1)C(=O)c1cc(N)ccc1-2</smiles>

III

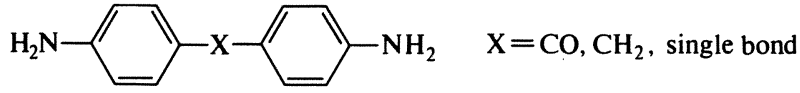

IV

Since the discovery of tilorone and its analogues a number of quite unrelated compounds have been shown to induce interferon formation in animals and some in humans. A series of pyrazolo-[3,4-b]quinolines (V) were discovered following an observation that the compounds when dosed to rats in an antimalarial test produced unusual basophilic granules in the peripheral lymphocytes, almost identical to those produced by tilorone. When the serum was checked for the presence of interferon it was positive. Mice dosed $400 \mathrm{mg} / \mathrm{kg}$ either orally or intraperitoneally gave 1,000-10,000 units/ml of circulating interferon, and the formation of vaccinia virus lesions could be prevented [103].

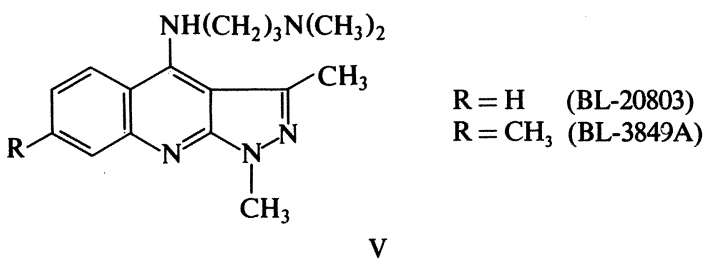

The development of this lead in animal experimentation [104, 105] and chemically [106] has been reported. Another type of diamine has been evaluated against both rhinovirus and influenza in human volunteers - N,Ndioctadecyl- $\mathrm{N}^{\prime}, \mathrm{N}^{\prime}$-bis(2-hydroxyethyl)-propanediamine (VI), code No. CP 20691.

$$
\left[\mathrm{CH}_{3}\left(\mathrm{CH}_{2}\right)_{17}\right]_{2} \mathrm{~N}-\left(\mathrm{CH}_{2}\right)_{3}-\mathrm{N}\left(\mathrm{CH}_{2} \mathrm{CH}_{2} \mathrm{OH}\right)_{2}
$$

VI

This compound has no direct antiviral effect, nor does it induce interferon in tissue culture, but an intraperitoneal injection in mice produces a high level of circulating interferon. It is not absorbed from oral dosing, but when applied to human volunteers intranasally as an oil in water emulsion at $50 \mathrm{mg} / \mathrm{ml}$, a local release or synthesis of interferon is induced and as much as $160 \mathrm{ug} / \mathrm{ml}$ could be detected in nasal washings. Moreover when thus administered, it gave statistically significant protection against a rhinovirus type 21 infection, 
in a double-blind placebo-controlled study in 39 volunteers [107]. An earlier clinical trial gave little evidence of a useful effect [108], and neither did a trial against influenza A2 [109].

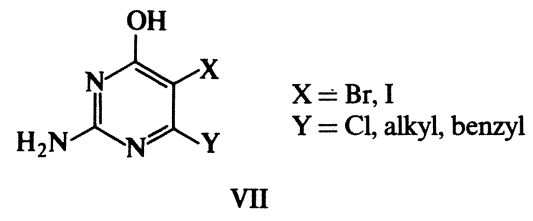<smiles>[R10]NCc1cccc(CN[R10])c1</smiles>

Using a mouse screen test for interferon inducers, workers at the Upjohn Laboratories discovered that certain 2-amino-4-hydroxypyrimidines (VII) were potent inducers when administered orally or parenterally. The minimum effective oral dose for antiviral activity (encephalomyocarditis virus) was about $250 \mathrm{mg} / \mathrm{kg}$ for the best compound (VII; X= Br, Y= $\mathrm{CH}_{3}$, code No. $\mathrm{U}-25166$ ) while the $\mathrm{LD}_{50}$ was $4 \mathrm{~g} / \mathrm{kg}$, [110]. This compound has been compared with tilorone and poly (rI:rC) in mice by Stringfellow [111], who found that approximately equal serum interferon levels were produced by 1,000 $\mathrm{mg} / \mathrm{kg}$ U-25166 orally, $250 \mathrm{mg} / \mathrm{kg}$ tilorone orally and $100 \mu \mathrm{g}$ poly (rI:rC) intraperitoneally. He found that it was consistently better than tilorone in terms of sensitivity to the onset of hyporeactivity on repeated dosing.

The phenylene dimethylene diamines (VIII) have substitution patterns related to the propanediamines (VI) in that $R_{1}$ and $R_{2}$ are short alkyl or $\omega$-hydroxyalkyl while $R_{3}$ and $R_{4}$ have from 12 to 24 carbons in the chain. They are claimed in recent patent literature as potent interferon inducers in rodents dosed parenterally or topically at $1-250 \mathrm{mg} / \mathrm{kg}$ [112].

Finally several mercaptoalkylamines, which are radiation protective agents, have been found to induce interferon in rodents when dosed i.p. The best compound (IX) protected mice from Semliki Forest virus and herpes simplex infections at $150 \mathrm{mg} / \mathrm{kg}$, and was relatively non-toxic, but analogues were very weak inducers [113].<smiles>N=C(N)SCCN</smiles>

IX

The field of interferon inducers is expanding rapidly but whether an ideal substance will ever be found is open to question. Hyporeactivity, the abolition of interferon response on repeated dosing of an inducer, seems a fundamental problem, as does the subtle form of toxicity encountered with both polymeric and low molecular weight inducers. Inducers have, however, been used with moderate success, as has exogenous interferon, in life-threatening infections and cancer and this gives great hopes for future developments. 
3 Alicyclic compounds

3.1 Adamantane derivatives

One might fairly claim that the whole course of development of antiviral compounds was suddenly changed by the advent of 1-aminoadamantane hydrochloride (X) in 1963 and its remarkably rapid approval for general use as a prophylactic treatment for the prevention of influenza caused by the A2/Asian strains of virus, by 1966. A novel area of chemistry, largely the preserve of academic research suddenly became of industrial importance and large teams of chemists were created to exploit the discovery.

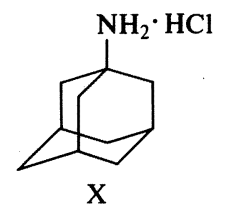

The early antiviral evaluation and clinical studies have been reviewed many times, e.g. [6], but attention is drawn to a review by one of the original discoverers, Hoffmann [114], while the early structure/activity relationships were discussed by Aldrich et al. [115]. Clinical trials were conducted over many years to find out how effective 1-aminoadamantane (amantadine, Symmetrel) was as a prophylactic treatment for influenza in closed communities of various kinds and in families. Many gave a positive result, e.g. [116], while others failed to show better effects than the placebo control [117] possibly for technical reasons, since the drug was undoubtedly effective under controlled conditions [114]. Much interest was shown by Russian health authorities in amantadine for prophylaxis and the population of whole towns were used in clinical trials. Currently, much of the work on analogues of amantadine is taking place in Russia with Danilenko and his colleagues in Kiev publishing a series of papers on synthesis and biological activity [118121], and groups at the Influenza research centres in Moscow, Leningrad and Riga reporting on synthesis, biological studies and clinical studies [122-124]. These groups have a great interest in $a$-methyl-1-adamantanemethylamine hydrochloride (XI, rimantadine) and its analogues.<smiles>CC(NCCl)C12CC3CC(CC(C3)C1)C2</smiles>

XI

Rimantadine, also discovered by the DuPont team, seems to have had relatively little attention paid to it compared with amantadine, although it is somewhat more active in vitro, has a wider antiviral spectrum inhibiting rubella, rubeola, respiratory syncytial and parainfluenza viruses as well as influenza A2 [125], and has both prophylactic [126] and therapeutic [127, 128] activity against influenza $\mathrm{A} 2$ in man. It was better tolerated than amantadine 
in man and in spite of an early adverse report that in man it caused some abnormalities in blood composition and in liver and kidney function [129] it has recently been hailed as a new wonder drug in Russia [130]. Its biochemistry is being studied [131, 132], it is being compared with bonaphthone (6-bromo-1,2-naphthoquinone) [133] and its combination with ribavirin is said to be synergistic [134]. Clinical studies have also been carried out in Poland [135]. The optical isomers of rimantadine have equal antiviral activity to the racemate in vitro [115]. The recently emerged variant of the old swine influen$\mathrm{za}$, influenza A/New Jersey/8/76 is sensitive to rimantadine in chick embryos. A dose of $2.5 \mathrm{mg} /$ embryo simultaneously with infection decreased the infectious titre by $10^{5}$ and inhibited the formation of viral haemagglutinin. This dose was not toxic to the embryos. The $a$-ethyl analogue also showed activity [136].

The third adamantane derivative of clinical interest has been N-methyl-2adamantyl-3'-spiropyrrolidine XII.

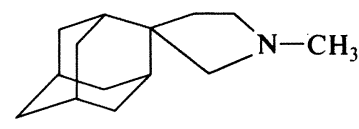

XII

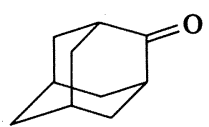

XIII

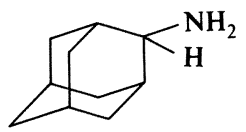

XIV

The 2-substituted adamantanes became available through the elegant oxidation/isomerization of 1-hydroxy adamantane or adamantane itself with $96 \%$ sulphuric acid to the 2-ketone (XIII) [137]. The 2-amino analogue (XIV) was active against all strains of influenza and had more activity than 1-amino adamantane against influenza $\mathrm{A} 2$. It was also active in vitro against rhinoviruses [138]. The spiro-compound XII was the most active of a series of 5-, 6- or 7-membered aza-spiro compounds with various substituents on the nitrogen atom. Substituents giving highest activity were $\mathrm{H}, \mathrm{CH}_{3}, \mathrm{C}_{2} \mathrm{H}_{5}$ [139-140]. It was tested in a human volunteer trial against Influenza A/Hong Kong/68 $\left(\mathrm{H}_{3} \mathrm{~N}_{2}\right)$, dosed orally $70 \mathrm{mg}$ b.i.d. for 7 days starting 2 days before infection with virus. It reduced the incidence of infections and the severity of reactions, was not toxic, and under the same conditions amantadine was inactive [141]. However, a trial against rhinovirus infection at the same dose gave no effect [142]. No further developments have been heard of in this series of adamantane derivatives, apart from a recent Japanese patent [143].

Other adamantane derivatives claimed as antiviral agents in recent patent literature are:

Adamantane derivative

Thioamides

Thioacetamides

Amidines

Pyrimidines

Ketones
Reference

144

145

146

147

148 
Imidoacid esters

Hydrazones of carbonyl derivatives

Carboxylic acid esters

Bis(aminomethyl)
149

150,151

152

153

A series of 1-adamantyl acetamides was evaluated against influenza, rhinovirus, herpes and vaccinia [154] and one member of the series, $\mathrm{N}$-(1-adamantyl)2-[(2-dimethylamino)ethoxy] acetamide (XV; tromantadine) tested clinically against various forms of superficial herpetic infections. The uncontrolled trials produced remission of symptoms in 5-6 days [155], which in herpes labialis can be about normal remission time in untreated cases. However, in a later study the compound, as the normal $1 \%$ ointment, produced contact allergy in $12 / 240$ patients [156].

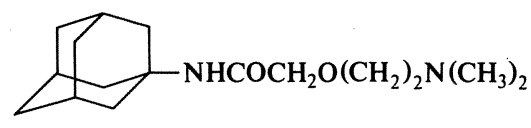

XV

Large numbers of novel 1- and 2-adamantyl derivatives have been reported, but have been inappropriately tested as virus disinfectants, interferon inducers or on viruses against which 1-aminoadamantane is totally inactive. None were tested against influenza, and the majority appeared inactive or nearly so in the tests to which they were submitted.

\subsection{Other alicyclic compounds}

Compared with the enormous interest in preparation and testing of amino derivatives of every polycyclic hydrocarbon during the years 1964-71, the past 7 years have been relatively quiet in this area. The early period was comprehensively reviewed [6] and the only clinically tested drug to emerge was cyclooctylamine hydrochloride (SKF 23880A), active in vitro at $50-100 \mu \mathrm{g} / \mathrm{ml}$ against influenza A0, A1, A2 and B [157]. Volunteers dosed intranasally six times per day with a $4 \%$ aqueous solution of the drug, so that a total daily dose of $150 \mathrm{mg}$ was administered, were partially protected against an influenza A2/Hong Kong challenge; 3/9 treated were free of disease compared with none in the control group, while 4/7 controls had severe symptoms compared to none in the treated group [158]. No further development of this drug seems to have taken place, apart from a recent detailed comparison of its activity in vitro and in vivo with amantadine, rimantadine and ribavirin [159]. The largest number of patents to have appeared recently (about 30) have been on derivatives of 4-homo-isotwistanes (tricyclo[5,3,1,03,8]undecanes) (e.g. XVIII). They are prepared by isomerizing many appropriate 11-carbon hydrocarbons (e.g. XVI) to 4-homo-isotwistane (XVII) which then will undergo reactions similar to those in the adamantane series. The only antiviral testing reported is 
not against influenza, but against Newcastle disease virus in chick embryo fibroblasts. In this system, 1-amino adamantane is inactive at $200 \mu \mathrm{g} / \mathrm{ml}$ and toxic to the cells at the same concentration. The 3-amino compound (XVIII) is active at $4.0 \mu \mathrm{g} / \mathrm{ml}$, toxic at $32 \mu \mathrm{g} / \mathrm{ml}$, while the 3-aminomethyl analogue is active at $8.0 \mu \mathrm{g} / \mathrm{ml}$, toxic at $16 \mu \mathrm{g} / \mathrm{ml}$. These are then claimed to be thirty to fifty times more active than aminoadamantane. The majority of other derivatives were inactive in the test system [160]. There are no reports of in vivo testing and we have found compound XVIII to be inactive in vitro against influenza $\mathrm{A} 0$ and $\mathrm{A} 2$ at $45 \mu \mathrm{g} / \mathrm{ml}$ [161].

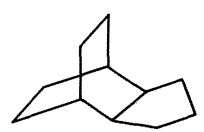

XVI

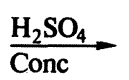

Conc

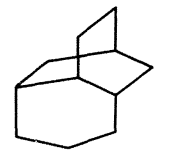

XVII

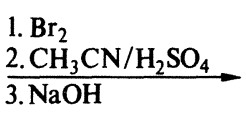
3. $\mathrm{NaOH}$

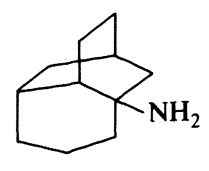

XVIII

4-Aminotwistanes (tricyclo[4,4,0,0 ${ }^{38}$ ]decanes, XIX) [162], 2-bornanemethylamines (XX) [163], 1-amino (XXI; $\mathrm{R}=\mathrm{NH}_{2}$ ) and 1-methylamino-7,7-dimethylnorbornanes (XXI; $\mathrm{R}=\mathrm{CH}_{2} \mathrm{NH}_{2}$ ) [164], bicyclooctane (XXII; $\mathrm{n}=2$ ) and norbornane (XXII; $n=1)$ spiropyrrolidines and spiropiperidines analogous to the 2-adamantylpyrrolidines [165], and aminospiranes (XXIII; $n=0$ ) or aminoalkylspiranes (XXIII; $n=1-3$ ) [166] have all been claimed recently as inhibitors of influenza virus.

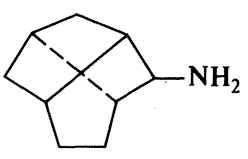

XIX<smiles>CC1C2CCC1(C)C1(CCN(C)C1)C2</smiles>

XXII<smiles>[R]C(N)C1CC2CCC1(C)C2(C)C</smiles>

$\mathrm{XX}$<smiles>[R]C1(C)C2CCC1(C)CC2</smiles>

XXI

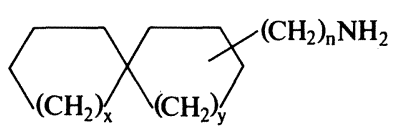

XXIII<smiles>C1CCC(C2CCCC3C2=C2CCCCC2C2CNCC32)CC1</smiles>

XXV 
The aminocyclopentylcarboxamide (XXIV) and several analogues are claimed as inhibitors of poliovirus in mice dosed 4-10 mg intraperitoneally [167], while a large series of bis-polymethylene isoindolines of which XXV is an example have activity against rhinoviruses with minimum inhibitory concentrations in vitro of $0.1-3.2 \mu \mathrm{g} / \mathrm{ml}$. Activity is also shown against coronavirus in vitro and equine rhinovirus in vivo in hamsters [168].

\section{$4 \quad$ Heterocyclic compounds \\ 4.1 Benzimidazoles}

Interest in this 'classical' area for antiviral actions has declined in recent years after a brief burst of activity early in the review period. 2-( $a$-Hydroxybenzyl)benzimidazole (XXVI; HBB) and its analogues were very thoroughly worked on in the late 1960's and early 1970's, when HBB was found to be a truly selective inhibitor of the replication of picornaviruses (polio, Coxsackie, Echo and bovine enteroviruses) [169].<smiles>OC(c1ccccc1)c1nc2ccccc2[nH]1</smiles>

XXVI

HBB inhibits specifically the synthesis of viral RNA. It has no effect on cellular metabolism and growth until doses of more than thirty times the antiviral dose are reached. Its antiviral action and biochemistry were fully reviewed by Caliguiri and Tamm [170]. Several groups prepared analogues, some checking very carefully for compounds with selective activity and others claiming activity where the ratio between toxicity and activity was 2 or less. In the former group, Gualtieri and colleagues found that activity against Echo 12 virus was retained when the $\mathrm{OH}$ group was methylated or replaced by $\mathrm{NH}_{2}$ or $\mathrm{NHCH}_{3}$. In addition the imidazole nitrogen could be substituted with $\mathrm{CH}_{3}$ or $\mathrm{C}_{6} \mathrm{H}_{5}$, retaining good activity [171]. In spite of high in vitro activities, no really successful in vivo protection against picornaviruses had been demonstrated, usually ascribed to rapid emergence of drug-resistant strains of virus - a feature readily observed in vitro. A recent paper by Eggers [172] claims successful treatment of Echo 9 and Coxsackie A9 virus infections of new born mice with a completely non-toxic synergistic mixture of $10 \mathrm{mM} \mathrm{D}-(-)-\mathrm{HBB}$ and $100 \mathrm{~mm}$ guanidine. The optically active $\mathrm{D}-(-)-\mathrm{HBB}$ is some $2.5-3$ times more active than $\mathrm{L}-(+)-\mathrm{HBB}$ and has the same toxicity as $\mathrm{L}-(+)$ and the racemic mixture. It has, therefore, even better selectivity than the racemate [173]. With the combination of HBB and guanidine administered subcutaneously only $4 / 111$ mice developed paralysis and one of the 4 died, while in untreated controls $94 / 102$ were paralysed and 80/94 died. The synergistic 
action of the mixture was very evident since with the same quantity of either $\mathrm{HBB}$ or guanidine alone all animals were infected and died. Eggers was surprised to find no evidence for the emergence of resistant strains of virus.

The most promising concept arising from the structure and activity of HBB, was the doubling up of the molecule to give 1,2-bis(2-benzimidazolyl)-1,2ethanediols, optionally substituted in the 5-position (XXVII).<smiles>[R]c1ccc2[nH]c(C(O)C(O)c3nc4cc([R])ccc4[nH]3)nc2c1</smiles>

XXVII

Activity against picornaviruses was maintained - Coxsackie and poliovirus strains but the novel feature was very high activity against all rhinovirus strains tested (55 strains) coupled with low toxicity to tissue culture cells [174]. The preferred compound was XXVII, $\mathrm{R}=\mathrm{OCH}_{3}$ with the two optically active centres in the $\mathrm{S}, \mathrm{S}$ configuration which was active against rhinovirus in vitro at $0.1 \mu \mathrm{g} / \mathrm{ml}$ but not toxic at $1,000 \mu \mathrm{g} / \mathrm{ml}$ - an enormous margin of selectivity. The compounds with configuration $\mathrm{R}, \mathrm{R}$ and $\mathrm{R}, \mathrm{S}$ were less active. Structure/activity relationships were investigated [175] by changing the $R$ substituents and the linking group between the benzimidazoles. 27 Bis-compounds and 11 monobenzimidazoles having the linking group as the 2-substituent were made. All the mono-compounds were inactive. Variations in the biscompounds were:

$$
\begin{aligned}
\mathrm{R}= & \mathrm{H}, \mathrm{OH}, \mathrm{OCH}_{3}, \mathrm{OC}_{2} \mathrm{H}_{5}, \mathrm{O}-\mathrm{n}-\mathrm{Pr}, \mathrm{CO}_{2} \mathrm{H}, \mathrm{Cl} \\
\text { Linking group }= & \mathrm{CH}_{2},\left(\mathrm{CH}_{2}\right)_{2}, \mathrm{CH}_{2}-\mathrm{CHOH},(\mathrm{CHOH})_{2},\left(\mathrm{CHCH}_{3}\right)_{2}, \\
& \stackrel{\mathrm{CH}_{2}-\mathrm{CH}_{2}}{\mathrm{CH}_{2}} \\
- & \stackrel{\mathrm{CH}}{\mathrm{CH}}-\stackrel{\mathrm{CH}}{\mathrm{C}}-, \quad(\mathrm{CHOH})_{4},(\mathrm{CHOAc})_{2}
\end{aligned}
$$

Highest activity was found with $(\mathrm{CHOH})_{2}$ and $\mathrm{R}=\mathrm{OCH}_{3}(0.1 \mu \mathrm{g} / \mathrm{ml})$ and $\mathrm{R}=\mathrm{OEt}(1.0 \mu \mathrm{g} / \mathrm{ml})$. When $\mathrm{R}$ was constant at $\mathrm{OCH}_{3} 3$ other linking groups produced compounds of low activity $(10 \mu \mathrm{g} / \mathrm{ml}),\left(\mathrm{CH}_{2}\right)_{2}, \mathrm{CH}_{2}-\mathrm{CHOH}$ and $(\mathrm{CHOAc})_{2}$. These studies were unfortunately incomplete when work on the project was terminated.

The lead compound (XXVII; $\mathrm{R}=\mathrm{OCH}_{3}$ ) gave high blood levels on oral dosing to mice and primate species and was finally tested in chimpanzees, the only species of animal apart from man in which rhinoviruses will cause infection [176]. Six chimpanzees were infected with rhinovirus 30 for the first series of tests and subsequently rhinovirus 49 and finally rhinovirus 44 . The results are given in the table. The drug was dosed orally three times per day to give the daily total stated in the table: 
Table

Results of treatment of rhinovirus infections in chimpanzees with Abbott 36683 (XXVII;

$\mathrm{R}=\mathrm{OCH}_{3}$ ).

\begin{tabular}{lllllr}
\hline Rhinovirus & Dose & For & \multicolumn{2}{l}{ Virus isolations } & Side \\
& mg/kg & days & \multicolumn{2}{l}{ Controls } & Treated \\
per day & & & & \\
\hline 30 & 100 & 4 & $3 / 3$ & $0 / 3$ & $3 / 3$ \\
49 & 50 & 4 & $3 / 3$ & $2 / 3$ & $0 / 3$ \\
49 & 15 & 4 & $3 / 3$ & $1 / 3$ & $0 / 3$ \\
44 & 100 & 1 & $3 / 3$ & $2 / 2$ & $0 / 2$ \\
\hline
\end{tabular}

The only dosing schedule to give a clearly positive result, $100 \mathrm{mg} / \mathrm{kg}$ per day for 4 days produced severe diarrhoea as the major side effect in all three treated animals, and I suspect that as a result of this finding the whole series was abandoned.

The mode of action of these compounds appeared to be similar to HBB, the inhibition of viral RNA synthesis [177]. A study of the urinary metabolites of the drug in mice was carried out [178], and further structure/activity relationships using poliovirus and adenovirus as test organisms were reported [179]. The last paper seen was a claim for in vitro activity against Junin virus, a small RNA virus of the Arbovirus group [180].

Other benzimidazole derivatives for which claims of anti-picornavirus activity have recently been made include 1-benzimidazole-2-phenyl-4-amino-butan-2ols (e.g. XXVIII) [181], a series of $\mathrm{N}^{1}$-sulphonyl-2-aminobenzimidazoles [182] and $\mathrm{N}^{1}$-thiazinyl or thiazolinyl-2-aminobenzimidazoles [183] of general formula XXIX.<smiles>CN(C)CCC(O)(C1=CC=C2C=CC=C1N2)c1ccccc1</smiles>

XXVIII<smiles>[R1]Nc1nc2ccc(OC([R])=O)cc2n1[X]</smiles>

$\mathrm{X}=\mathrm{SO}_{2} \mathrm{CH}\left(\mathrm{CH}_{3}\right)_{2} \quad \mathrm{XXIX}$<smiles>CC1=NCCS1</smiles><smiles>CC1=NCCCS1</smiles> 


\subsection{Thiosemicarbazones and related compounds}

Thiosemicarbazones of heterocyclic aldehydes and ketones have continued to be of interest as antiviral agents. The spectrum of activity in vivo has not widened appreciably except to include activity against tumour viruses in rodents, but in vitro novel effects are being demonstrated against a range of DNA and RNA viruses particularly when thiosemicarbazones are complexed with metal ions from the first transition series, e.g. $\mathrm{Cu}, \mathrm{Zn}, \mathrm{Fe}, \mathrm{Co}, \mathrm{Ni}$ and $\mathrm{Mn}$. The state of knowledge to 1973 was well reviewed by Levinson [184]. Subsequently, several groups are reporting syntheses of new thiosemicarbazones with anti-vaccinia activity [185-187], and of isatin isothiosemicarbazones (e.g. XXX) [188-190] which have activity against Mengo virus in FL cells.
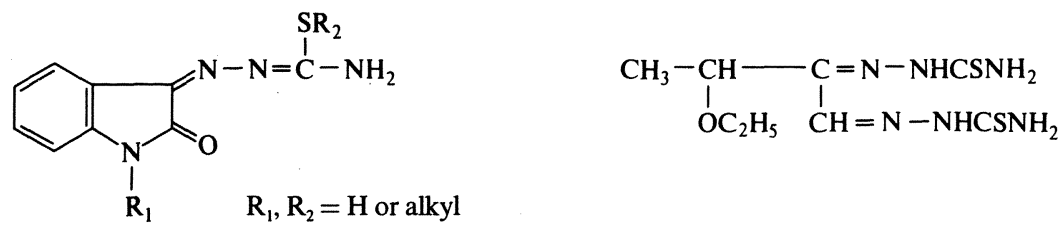

$\mathrm{XXX}$

XXXI

Activity is much more influenced by variation of $R_{1}$ than by $R_{2}$. Kethoxal bisthiosemicarbazone (XXXI) inhibits replication of vesicular stomatitis virus, an RNA virus, in chick embryo cells at $0.02 \mu \mathrm{g} / \mathrm{ml}$. Visible cell toxicity is observed at $0.16 \mu \mathrm{g} / \mathrm{ml}$. N-Methylisatin- $\beta$-thiosemicarbazone and 2-formylpyridine thiosemicarbazone do not show any effect in this system. Although XXXI is a powerful chelating agent it did not inactivate the virus on contact [191]. The ability of 1,2-bis-thiosemicarbazones to act as tetradentate ligands, and certain mono-thiosemicarbazones as tridentate ligands for divalent metal ions, particularly copper and zinc, has led to much speculation on whether this is their mode of action. Many thiosemicarbazones inactivate viruses extracellularly on contact [192], but in the presence of $\mathrm{Cu}^{++}$ions they do so much more rapidly and at lower concentrations [193, 194]. This concept has been extended to other copper-binding ligands, e.g. 8-hydroxyquinoline and isonicotinic hydrazide which will inhibit malignant transformation of cells by Rous sarcoma virus and also inactivate the virus extracellularly [195]. It is speculated that these compounds scavenge copper ions and transport them to the virus in an efficient manner causing viral inactivation. However, thiosemicarbazones also inhibit RNA-dependent RNA and DNA polymerases which are known to be zinc containing metalloenzymes. 2'-Acetylpyridine-3-thiosemicarbazone (XXXII) inhibits the activity of the RNA-dependent RNA polymerase (RNA transcriptase) in influenza $\mathrm{B} / \mathrm{LEE} / 40$ virus by $50 \%$ at $0.002 \mathrm{~mm}$ concentration, isatin $\beta$-thiosemicarbazone $(\mathrm{XXXIII} ; \mathrm{R}=\mathrm{H})$ at $0.02 \mathrm{~mm}$ and $\mathrm{N}$-methylisatin- $\beta$-thiosemicarbazone (XXXIII; $\mathrm{R}=\mathrm{CH}_{3}$ ) at $0.1 \mathrm{~mm}$ [196]. Although the modest action of these compounds could be the sequestration of the essential zinc atoms from the transcriptase, they do not have any activity 
against influenza in vivo in either mice or ferrets [196]. A detailed review of inhibition of metallo-enzymes as an approach to antiviral chemotherapy has appeared [197].<smiles>CC(=NNC(N)=O)c1ccccn1</smiles>

XXXII<smiles>[R]N1C(=O)/C(=N\NC(N)=O)c2ccccc21</smiles>

XXXIII

A novel development in the prophylaxis of virus infections using thiosemicarbazones, thiosemicarbazide, semicarbazide, hydrazine and aminoguanidines is reported in recent American Home Products Corporation patents [198]. Oral administration of minute quantities ( $250 \mathrm{pg}$ to $250 \mu \mathrm{g} / \mathrm{kg}$ ) of these compounds to mice, rabbits and embryonated eggs before challenge with a wide variety of RNA and DNA viruses, conferred protection on $30-60 \%$ of animals, while all untreated control animals died. No explanation of this curious phenomenon was given except in terms of non-specific augmentation of host resistance.

\subsection{Triazinoindoles}

These (XXXIV) are cyclization products of isatin $\beta$-thiosemicarbazones. Displacement of the resultant 3-SH group with a variety of amino alcohols has given a series of triazino[5,6-b]indoles (XXXV) with strikingly high activity against many strains of rhinovirus in vitro.

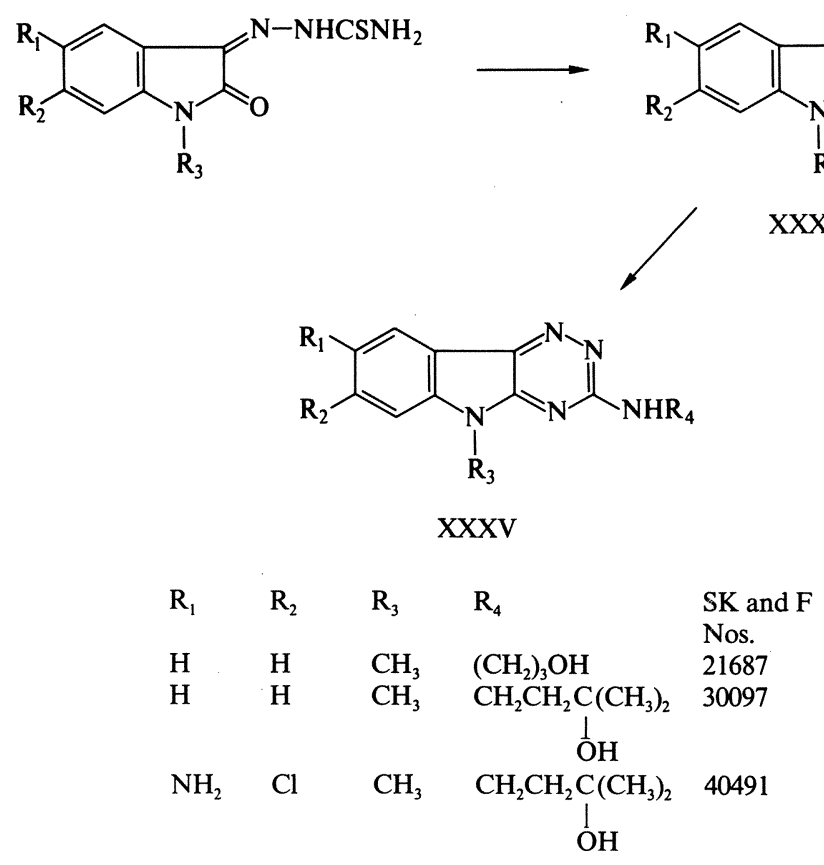


The compounds were active in vitro not only against rhinovirus but against Coxsackie, Echo, herpes, polio, pseudorabies and vaccinia viruses [199]. The wide range of compounds and their structure/activity relationships were described by Gladych [200], but the three which were studied most and finally taken to human clinical trial are given above, SK and F Nos. 21687, 30097 and 40491. Minimum inhibitory concentrations of 40491 against rhinovirus strains in vitro were $0.8-3.5 \mu \mathrm{g} / \mathrm{ml}$ and not toxic at $100 \mu \mathrm{g} / \mathrm{ml}$. Blood levels of $5.2 \mu \mathrm{g} / \mathrm{ml}$ could be obtained in primates from an oral dose of $25 \mathrm{mg} / \mathrm{kg}$ and there were no signs of toxicity. A trial of 40491 in infected gibbon monkeys gave an encouraging result [201]. An animal metabolic study of SK and F 21687 gave no cause for concern [202] and in humans a dose of $3 \times 1 \mathrm{~g}$ per day orally of SK and F 30097 was well tolerated [203]. However, a human clinical trial of 21687 and 30097 dosed intranasally at $200 \mathrm{mg} /$ day in 6 divided doses of a $5 \%$ aqueous suspension for 7 days, showed no difference in infection rate, virus shedding or clinical symptoms between treated and control patients [204]. A subsequent trial of these two compounds dosed orally was negative as was a trial of SK and F 40491 administered as a nasal spray [205].

The only subsequent work in this area has been an investigation of the effect on antiviral activity of exchanging the positions of $\mathrm{N}-2$ and $\mathrm{C}-3$ with its aminoalcohol side chain [206].

\subsection{Other heterocyclic antivirals}

The purine and pyrimidine nucleoside analogues together with virazole and similar ribofuranosyl derivatives of nitrogen heterocycles will be reviewed in the next section. Here I have selected a few of the enormous number of heterocyclic compounds for which, during the last few years, antiviral activity has been claimed.

For many claims, only minimal investigation of compound toxicity has been carried out. It is particularly easy to find anti-herpes virus activity with compounds which inhibit DNA synthesis, cellular as well as viral. Such inhibition is not readily detectable in in vitro test systems as it does not show as a cytopathic effect in confluent cell cultures. Similarly, other adverse effects on cellular functions make antiviral action non-specific. An example of this is 3-methylene oxindole (XXXVI) which was claimed to be a specific inhibitor of herpes, mengo, polio and Sindbis viruses at $10 \mu \mathrm{M}$ concentration, acting by prevention of binding of viral messenger RNA to host cell ribosomes [207, 208]. However, more detailed work on the effect of (XXXVI) on cellular functions has shown that both viral and cellular protein synthesis are equally inhibited by the same concentration of drug and the drug is preventing binding of cell messenger RNA's as well as the viral and is, therefore, nonspecific [209].

Several 1-substituted dihydro-isoquinolines related to the acetamide (XXXVII) were claimed to be inhibitors of viral neuraminidase and thus of 
possible use against influenza virus which carries neuraminidase as a surface enzyme. A later investigator claimed that the colourimetric assay used in the above work for neuraminidase had given completely false results, the colour being produced by one of the components of the assay mixture, not the neuraminidase [210]. In spite of this, the compounds, including (XXXVII), inactivated myxoviruses when incubated together. (XXXVII) was active in vivo, but not in vitro against influenza, Echo 9, Columbia S.K. and herpes viruses. It was of low toxicity to animals and a single dose of $4 \mathrm{~g}$ to human volunteers had no adverse effects [211]. It was tested in a double-blind clinical trial, not against influenza but against rhinovirus strain 24. Oral dosage of $2 \mathrm{~g}$ per day in 4 divided doses for 7 days did not produce any adverse effects, but neither was the course of infection altered, 9/10 drug treated volunteers being infected compared with $10 / 11$ placebo treated. The treated patients all had less severe symptoms and shed less virus than the controls [212].<smiles>C=C1C(=O)Nc2ccccc21</smiles>

XXXVI<smiles>NC(=O)CC1=NCCc2ccccc21</smiles>

XXXVII

Hydantoin derivatives have been claimed as antivirals. $L(-)-5-\left(3^{\prime}, 4^{\prime}\right.$-dichlorophenyl)-5-methyl hydantoin (XXXVIII) provided complete protection to mice against lethal Coxsackie A21 virus infections when dosed orally at $5 \mathrm{mg} / \mathrm{kg}$ [213].<smiles>CC1NC(=O)NC(=O)C(C)(c2ccc(Cl)c(Cl)c2)C1=O</smiles>

XXXVIII<smiles>[R]N1C(=O)C(=Cc2ccccc2)N([R])C1=O</smiles>

XXXIX

More recently, 5-benzylidene hydantoins (XXXIX) with various substituents in the aromatic ring were reported to have very high activities against rhinoviruses, polio, Coxsackie, Echo and foot-and-mouth disease viruses. Mono-Nacylated hydantoins had higher activity than the unsubstituted, and in general bis-N-acylated had more activity than mono. A preferred compound, 5-(3',4'dimethoxybenzylidene)-N,N-diacetyl hydantoin, was active against rhinovirus strains at $0.01 \mu \mathrm{g} / \mathrm{ml}$ when the maximum concentration, not showing visible cytotoxic effects, was $10 \mu \mathrm{g} / \mathrm{ml}$. The growth of polio and Coxsackie viruses was inhibited $50 \%$ at $0.02 \mu \mathrm{g} / \mathrm{ml}$. A single dose of $100 \mathrm{mg} / \mathrm{kg}$ to guinea-pigs gave detectable serum levels of drug up to 6 hours later [214, 215]. No further reports of this interesting group of compounds have been seen. 
There has been much interest in 5,5-ring fused heterocycles, stimulated probably by the many actions of levamisole (L-(-)-6-phenyl-2,3,5,6-tetrahydroimidazo[2,1-b]thiazole, XL) an anthelmintic and stimulator of immune responses, reviewed in volume 20 of this series [216]. It is not an antiviral agent in vitro but will protect animals against viral challenge and has been used in several trials against herpes simplex virus in man. In one of these, twelve patients with recurrent genital herpes were treated with levamisole $150 \mathrm{mg}$ orally twice weekly for 4-9 months. 8/12 Reported much reduced frequency of recurrence and 6/12 decreased duration of the eruptive phase [217]. Trials against virus induced and other tumours in animals have been very numerous, see [216]. The activities of levamisole and inosiplex (see next section) another immunostimulant and antiviral agent have been compared by Hadden [218]. The closely related compound 2,6-diphenyl-3-methyl-2,3dihydroimidazo[2,1-b]thiazole (XLI; RP 19326) has good activity in vitro against rhinovirus strains. In Hela cells, $4.0 \mu \mathrm{g} / \mathrm{ml}$ reduced the yield of rhinovirus 9 by $2.4 \log$ compared with untreated control and had no cytotoxic effect at $32 \mu \mathrm{g} / \mathrm{ml}$. Despite this excellent effect in vitro, only slight beneficial effects were observed in a human volunteer clinical trial in which it was dosed intranasally as a spray thirteen times per day for 4 days [205].<smiles>c1ccc(C2CN3CCSC3=N2)cc1</smiles>

$\mathrm{XL}$

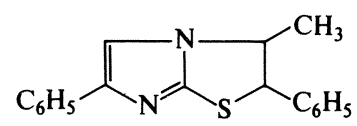

XLI<smiles>c1cc2n(n1)CCN2</smiles>

XLII

2,3-Dihydro-1H-imidazo[1,2-b]pyrazole (XLII) has anti-tumour properties and had been claimed to have anti-herpes virus activity. Pelling and Shipman [219] examined the claim carefully and established methods to test for the degree of selectivity of observed antiviral effects and found that the compound at all concentrations was not selective, inhibiting cellular DNA replication more than viral DNA.

Another heterocycle tested recently in human volunteers against rhinovirus was 3-a-naphthyl-5-diethylcarbamoyl-1,2,4-oxadiazole (XLIII; GL-R 9338). In vitro, it gave a reduction in virus titre of $2.8 \mathrm{log}$ at $4.0 \mu \mathrm{g} / \mathrm{ml}$ but only against rhinovirus strain 9. It was virtually inactive against three other strains. In the human trial it was dosed as intranasal drops of a $2.25 \%$ suspension five times per day (15 mg drug/day) for 4 days. There was no difference in<smiles>CCOC(=O)c1nc(-c2cccc3ccccc23)no1</smiles>

XLIII<smiles>CSc1ccc(C=Cc2noc(N(C)C)n2)cc1</smiles>

XLIV 
symptoms between treated and control groups although less virus was shed by the treated group - a very similar picture to RP 19326 above [205]. A small series of oxadiazoles had been reported a few years earlier to have activity against rhino-, adeno-, herpes and parainfluenza viruses, by the same research group (e.g. XLIV) [220] and GL-R 9338 was clearly a development of the earlier lead.

Rhodanine (XLV) is still a useful tool for unravelling the complexities of the action of antiviral agents. Eggers and his co-workers have been studying the effect of rhodanine on Echo 12; an enteric RNA virus for many years. Their latest paper indicates that it selectively prevents the removal of the protein coat of the virus when the virus enters the host cell, so that infectious RNA is not released [221].<smiles>O=C1CSC(=S)N1</smiles>

XLV<smiles>Oc1nc2ncc(Br)nc2nc1O</smiles>

XLVI<smiles>Nc1cc2[nH]ncc2c(=O)[nH]1</smiles>

XLVII

The pyrazino-pyrazine (XLVI) has activity in vitro against herpes simplex with an $\mathrm{ED}_{50}$ of $4 \mu \mathrm{g} / \mathrm{ml}$, and against vaccinia at $15 \mu \mathrm{g} / \mathrm{ml}$. The concentration causing a $50 \%$ reduction in growth of the test cells (HeLa cells) was $67 \mu \mathrm{g} / \mathrm{ml}$ [222]. Many heterocyclics were synthesized as close or remote analogues of purines and pyrimidines hoping for safe interference with DNA synthesis. One such compound recently reported is 6-aminopyrazolo[4,3-c]pyridin$4(5 \mathrm{H})$-one (XLVII), [223] which is an analogue of guanine and 3-deazaguanine. The latter has antiviral activity against herpes, parainfluenza and rhinovirus, in vitro, but compound (XLVII) differing only in the position of N-8 has lost all antiviral activity. The recent human trial on 1-phenyl-3-(4'phenyl)-2-thiazolylguanidine is reported in the section on amidines and guanidines (p. 299).

\section{$5 \quad$ Nucleoside analogues}

This, I think, is the most difficult area of antiviral chemotherapy. The chemistry is not often simple to achieve, but the safety evaluation of analogues of natural pyrimidines and purines which may block or incorporate into the complex synthetic pathways of normal cell metabolism and reproduction is extraordinarily difficult. Their main activities are against DNA viruses such as herpes viruses which can cause severe, life-threatening illness and against RNA tumour viruses and human cancers. Several are used clinically and 5-iododeoxyuridine is the one antiviral agent which can be said to be in common use. 


\subsection{Virazole}

Virazole (ribavirin, 1- $\beta$-D-ribofuranosyl-1,2,4-triazole-3-carboxamide; XLVIII) is a potent inhibitor of a wide range of RNA and DNA viruses and has been claimed as the first genuine broad-spectrum antiviral agent.<smiles>NC(=O)c1ncn(C2(O)C3OC(O)(C3O)C2O)n1</smiles>

XLVIII<smiles>NC(=O)c1ncn(C2(O)OC(OP(=O)(O)O)C(O)C2O)n1</smiles>

XLIX<smiles>NC(=O)c1nc[nH]n1</smiles>

$\mathrm{L}$

Its synthesis and antiviral properties were first reported in 1972 [224, 225]. Its mode of action seems to be inhibition of the enzyme inosine monophosphate dehydrogenase, which results in decreased synthesis of guanine nucleosides causing inhibition of viral nucleic acid synthesis [226]. The detailed consequences of inhibition of guanine nucleosides by virazole have been discussed by Lowe [227]. The active entity in cells and animals is probably the monophosphate (XLIX). The triazole carboxamide base (L) has similar activity to virazole in vivo and appears to be metabclized to virazole. The biochemistry of this process has been described [228]. This paper is the first of a series of 11 papers on virazole which give an up-to-date account of metabolism, lack of immunosuppressive activity, effect on herpes virus type 2, inability to develop resistant strains of herpes virus, effect on viral hepatitis in animals and humans and on influenza in humans, mice and primates [229]. The activity of virazole against influenza has been of major interest. In vitro the $50 \%$ inhibitory dose is around $1.0 \mu \mathrm{g} / \mathrm{ml}$ and it appears non-toxic to cells at $100 \mu \mathrm{g} / \mathrm{ml}$. It has been shown that virazole triphosphate specifically inhibits influenza virus RNA polymerase $(90 \%$ at $500 \mu \mathrm{M}, 50 \%$ at $100 \mu \mathrm{M})$ while virazole and its monophosphate are inactive [230]. A large number of tests in mice against influenza and parainfluenza, e.g. [231] have given excellent results prophylactically and therapeutically. However, in human trials the effect has not been encouraging, some giving no positive effect [232] others a slight amelioration of symptoms at doses of $1.0 \mathrm{~g} /$ day [233] and one, in a natural outbreak of influenza in a girl's school, apparently successful with a dosage of $100 \mathrm{mg}$ t.i.d. once symptoms of influenza were apparent. 16/25 Patients had severe illness on placebo while signs of illness were absent in $15 / 21$ treated with virazole [234].

Although much clinical work has been done on this compound, up to early 1977 100,000 people had taken it orally without evidence of more than slight 
and transient side effects, it will in vitro inhibit cellular DNA synthesis by $50 \%$ at $1.0 \mu \mathrm{g} / \mathrm{ml}$ which is the same concentration at which influenza replication is inhibited by $50 \%$ [235]. This immediately leads to questions of safety. Kilham and Ferm [236] have reported that small single doses $(1.25-4.2 \mathrm{mg} / \mathrm{kg})$ given i.p. to female hamsters on the 8 th day of pregnancy caused widespread tetratogenic abnormalities and resorptions of fetuses. At $6.25 \mathrm{mg} / \mathrm{kg} 100 \%$ of fetuses were resorbed. Similar effects have been found in rats dosed $20 \mathrm{mg} / \mathrm{kg}$, although in in vivo tests for mutagenicity it appears negative at doses up to $150 \mathrm{mg} / \mathrm{kg}$ [237]. These results serve to emphasize the difficulties of safety evaluation in nucleoside analogues.

The search for analogues of virazole has produced among the more interesting variations:<smiles>[R]C12CC(O)(C(CO)O1)C2(C)O</smiles>

LI<smiles>[R]C12CC(CO)(SC1(O)O)C2(C)O</smiles>

LII<smiles>[R]C1(C)CCCO1</smiles>

LIII
LI: $\mathrm{R}=$<smiles>Cn1cnc(C(N)=S)n1</smiles><smiles>[X]c1c(OC(N)=C=[R])ncn1C</smiles>

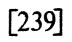<smiles>Cn1cnc(C(=N)N)n1</smiles>

[238]<smiles>CN1N=NNC1N</smiles><smiles>[R]=COc1csc(C)n1</smiles>
[241] [240]<smiles>Cc1nc(ON)n[nH]1</smiles><smiles>[R]=[W]</smiles><smiles>[R]=C[AlH2]Oc1ncn(C)n1</smiles>
[244]

All variations seem to be less active than virazole itself and many lose activity altogether. 
5.2 Arabinosyl nucleosides and nucleotides

Replacement of the ribose moiety of naturally occurring nucleosides by arabinose, i.e., changing the $2^{\prime}-\mathrm{OH}$ from the $a$ to the $\beta$ configuration, is sufficient to render them foreign to enzymes in the DNA and RNA pathways so that these paths are blocked either partially or completely. Some of the blockages are more selective for virus polynucleotides than for the corresponding cellular ones, and so the search for clinically useful antiviral agents has generated and still generates an enormous amount of work in this area.

A very comprehensive review of the topic to 1973 was written by Ch'ien, Schabel and Alford [245]. The proceedings of a 1975 conference on the chemistry, biology and clinical uses of nucleoside analogues contained many papers on arabinosyl analogues [246], while the proceedings of the Third Conference on Antiviral Substances has a section containing 10 papers devoted adenosine arabinoside [247].

\section{$5.219-\beta$-D-Arabinofuranosyladenine (Ara-A, LIV)}

Ara-A seems so far to be the most active and least toxic in vivo of all the arabinosyl analogues, and has been used clinically with success dosed at 5-20 $\mathrm{mg} / \mathrm{kg}$ per day against herpes simplex [248-251], varicella zoster [252, 253], cytomegalovirus [253] and adenovirus [254]. Like all nucleoside analogues it has to be dosed parenterally or where appropriate topically. It is a poorly soluble compound $(0.5 \mathrm{mg} / \mathrm{ml})$ which restricts certain routes of administration, but its $5^{\prime}$-monophosphate is very soluble in water, is no more toxic, has little irritancy by intramuscular injection at $40 \% \mathrm{w} / \mathrm{v}$ and has identical antiviral properties. Surprisingly the $5^{\prime}$-monophosphate is not teratogenic in rabbits at $25 \mathrm{mg} / \mathrm{kg}$ intramuscularly, although Ara-A at $5 \mathrm{mg} / \mathrm{kg}$ is teratogenic [255].<smiles>Nc1ncnc2c1ncn2C1OC2CC1C(O)C2(O)CO</smiles>

LIV

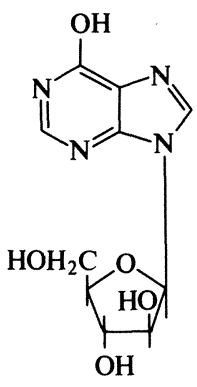

LV<smiles>[R]C1C(O)C2(CO)OC1(CO)C21CNC=Nc2c1ncn2O</smiles>

LVI

Ara-A is rapidly deaminated in vivo by adenosine deaminase to hypoxanthine arabinoside (LV) which is a much less active antiviral. Against varicella zoster it is forty to fifty times less active [256]. In spite of this it has been frequently 
evaluated alongside Ara-A and used in combined treatment of DNA virus disease, e.g. [257]. Its 5'-monophosphate was evaluated in vivo by the I.C.N. group [258]. Inhibitors of adenosine deaminase are potentially useful in improving the effect of Ara-A. Two highly active inhibitors are Co-formycin (LVI; $\mathrm{R}=\mathrm{OH}$ ) and Co-vidarabine (LVI; $\mathrm{R}=\mathrm{H}$ ), both microbial metabolites which are particularly difficult to isolate [259]. Co-vidarabine certainly enhances the effect of Ara-A in vitro and in vivo [260] but it simultaneously makes Ara-A more toxic [261].

The Ara-A molecule has been substituted in every possible position in the search for improved properties. The $2^{\prime}, 3^{\prime}-\mathrm{OH}$ have been methylated [262], the 6-amino function has been hydroxylated [263], the 2-position substituted by $\mathrm{NH}_{2}$ and $\mathrm{OH}$ [264], the $\beta$-D-arabinose replaced by $\alpha$-D-arabinose [265], the arabinose replaced by 4-hydroxymethyl-2,3-dihydroxy cyclopent-1-yl [266], the $3^{\prime}, 5^{\prime}$-cyclic phosphate prepared [267] and the $8-\mathrm{CH}$ replaced by nitrogen [268]. Finally, 45 analogues were reported by Haskell [269] and their structure-activity relationships discussed.

\section{$5.22 \quad 1-\beta$-D-Arabinofuranosylcytosine (Ara-C, LVII)}

Ara-C was fully reviewed in 1973 [245] with details of in vitro and in vivo reports on its antiviral activity, biochemical mechanism of action, clinical pharmacology, usage in human virus diseases and toxicity. It is definitely much more toxic than Ara-A in animals and humans and most authors conclude that it is just as damaging to the host as to the virus [270, 271]. Ara-C is rapidly deaminated in vivo to uridine arabinoside (LVIII) which is not active as an antiviral agent, so that if low doses are given to avoid toxicity, no antiviral effect can be demonstrated because all the dose is deaminated. It is still used systemically as a last desperate measure in severe life-threatening DNA virus infections when all else has failed.<smiles>Nc1ccn(C2OC3(CO)OC(O)C2C3O)c(=O)n1</smiles>

LVII<smiles>O=c1nc(O)ccn1C12OC(CO)C(O1)C(O)C2O</smiles>

LVIII

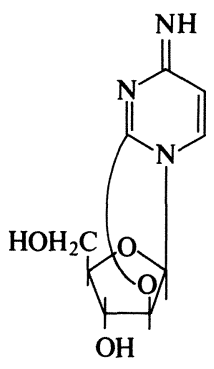

LIX

The antiviral effects of Ara-C are frequently compared with those of Ara-A and other agents in various test systems - rabies in vitro and in vivo [272], herpes simplex encephalitis in mice [273, 274], selective inhibition of viral DNA synthesis [275], cytomegalovirus in mice [276]. 
In the search for less toxic compounds, many analogues of Ara-C have been prepared. The arabinose hydroxyls have been alkylated but gave inactive compounds [277] and acylated to give activity when the acyl groups are enzymically hydrolyzed in vivo to free Ara-C [278, 279], while the 4- $\mathrm{NH}_{2}$ group has been acylated with a large variety of groups including peptides [280]. Removal of the elements of water between the 2- and 2'-positions of Ara-C gives 2,2'-anhydro-1- $\beta$-D-arabinofuranosylcytosine (cyclocytidine; LIX). This derivative has activity against herpes virus in vitro at $0.1 \mu \mathrm{g} / \mathrm{ml}$ which is fifty times greater than Ara-C. In man, a subcutaneous injection is readily absorbed and provides a constant level of Ara-C over several hours by slow hydrolysis ( $\mathrm{t}_{1 / 2}$ is about $8 \mathrm{hrs}$ ). It is still fairly toxic but less so than Ara-C [281]. Its antiviral properties in vitro and in vivo have been compared recently with those of Ara-C [278, 279]. Acylation of the $3^{\prime}$ - and 5'-hydroxyls gave a wide range of active compounds [282], while the $5^{\prime}$-monophosphate [283] and $3^{\prime}, 5^{\prime}$-cyclic monophosphate $[284,285]$ have been reported equi-active with Ara-C.

\subsection{3}

\section{1- $\beta$-D-Arabinofuranosylthymine (Ara-T, LX)}

This recent addition to the arabinosyl nucleoside analogues is claimed to have high $(0.5-5.0 \mu \mathrm{g} / \mathrm{ml})$ and specific activity against herpes virus types 1 and 2 and against equine herpes virus in vitro [286]. It is remarkably non-toxic to uninfected cells, not interfering with the rate of cellular replication at $50 \mu \mathrm{g} / \mathrm{ml}$ and its activity seems to be directed specifically against the synthesis of viral DNA [287].<smiles>Cc1cn(C23CCC(O2)C(O)C3O)c(=O)[nH]c1=O</smiles>

LX<smiles>Cc1cn(C23CCC(O2)C(O)C3O)c(=O)nc1N</smiles>

LXI

Tested in vivo in hamsters against equine herpes virus it showed only a prolongation of survival time. No cures were effected and it appeared that it was metabolized very rapidly [288]. In this paper, preliminary tests on 1- $\beta$-Darabinofuranosyl-5-methylcytosine (LXI) are reported, which was designed to be an intracellular donor of Ara-T by deamination. In cells which did not possess deoxycytidine deaminase (e.g. baby hamster kidney cells) it was totally inactive, but in cells possessing the enzyme (e.g. HEp-2 cells) it was equi-active 
to Ara-T. No in vivo experiments were reported. $1-\beta$-D-Xylofuranosylthymine (LX; $2^{\prime}-\alpha-\mathrm{OH}, 3^{\prime}-\beta-\mathrm{OH}$ ) [289], 9- $\beta$-D-xylofuranosyl guanine, its $5^{\prime}$-monophosphate and $3^{\prime}, 5^{\prime}$-cyclic monophosphate [290] all have moderate activity against DNA viruses but are less effective than Ara-A. This indicates that inversion of the $3^{\prime}$-position of ribose is also an effective means of misleading enzymes in the DNA virus synthetic pathway.

\subsection{Halogenated pyrimidines}

The first specific chemotherapeutic agent effective against a virus disease to receive approval for clinical use was a halogenated pyrimidine, 5-iodo-2'deoxyuridine ( $\mathrm{LXII} ; \mathrm{R}=\mathrm{I}, \mathrm{R}^{\prime}=\mathrm{OH}$ ) tested in man against herpes keratitis in 1962 [291]. The enormous interest generated by this success still continues. Results to 1973 were comprehensively reviewed by Sugar and Kaufman [292] and the molecular pharmacology of these compounds was briefly reviewed in the same year [293]. 5-Iodo-2'-deoxyuridine (IUdR) is often compared for potency against other nucleoside analogues.<smiles>[R]c1cn(C23CC(C([R4])O2)C3O)c(=O)[nH]c1=O</smiles>

LXII

One recent comparison carried out with several carefully standardized in vitro test methods on 5 strains of type 1 and 5 strains of type 2 herpes simplex virus showed that Ara-C was the most potent inhibitor followed by IUdR and trifluorothymidine (LXII; $\mathrm{R}=\mathrm{CF}_{3}, \mathrm{R}^{\prime}=\mathrm{OH}$ ). Ara-A and Ara-DAP were the least active overall [294]. Another comparison with Ara-A, Ara-C, virazole and phosphonoacetic acid tested in mice against herpes simplex was reported by Harris and Boyd [295].

Although IUdR works well against superficial herpes and zoster infections, much controversy has arisen over its use in disseminated and encephalitic herpes infections, as some trials indicate a positive effect and an almost equal number show no effect. Two trials in animal models - equine herpes virus type 1 in mice [296] and herpes virus hominis in marmosets [297] gave no reduction of virus in brain tissue although there was a reduction of virus titre in blood and visceral organs.

The analogous 5-bromo-2'-deoxyuridine ( $\mathrm{LXII} ; \mathrm{R}=\mathrm{Br}, \mathrm{R}^{\prime}=\mathrm{OH} \mathrm{BrUdR}$ ) is suspected of activating DNA and RNA virus replication in cells where the 
virus is latent, and some research groups have indicated that this occurs with IUdR as well [298-300].

IUdR is a moderately cytotoxic compound with a therapeutic ratio of about 4 , and much work has been done in the search for less toxic analogues. 5'-Amino-2',5'-dideoxy-5-iodouridine ( $\mathrm{LXII} ; \mathrm{R}=\mathrm{I}, \mathrm{R}^{\prime}=\mathrm{NH}_{2}, \mathrm{AIU}$ ) is remarkably non-toxic to uninfected cells, no inhibition of growth being observed in the presence of $400 \mu \mathrm{M}$, and to baby mice in which $450 \mathrm{mg} / \mathrm{kg}$ doses produced no detrimental effects on growth or development. IUdR at $125 \mathrm{mg} / \mathrm{kg}$ arrested growth of these mice and caused much organ damage. AIU has, however, a restricted antiviral spectrum having high activity only against herpes virus type 1 and murine leukaemia virus in vitro. The compound is incorporated into virus and host cell DNA only in virus infected cells, which is a remarkable form of selectivity and obviously virus induced. In herpes keratitis in rabbits it is less effective at $8 \mathrm{mg} / \mathrm{ml}$ topically than IUdR at $1 \mathrm{mg} / \mathrm{ml}$ [301-303]. The analogous $5^{\prime}$-azido derivative ( $L X I I ; R=I, R^{\prime}=N_{3}$ ) showed no significant antiviral activity [303].

If the 5-iodo-substituent is replaced by 5-trifluoromethyl giving a thymidine analogue ( $\mathrm{LXII} ; \mathrm{R}=\mathrm{CF}_{3}, \mathrm{R}^{\prime}=\mathrm{NH}_{2}$ ), the product again has a narrower range of activity than the parent ( $\mathrm{LXII} ; \mathrm{R}=\mathrm{CF}_{3}, \mathrm{R}^{\prime}=\mathrm{OH}$ ), is four times less potent on a molar basis but is forty times less toxic when tested in Vero cells against herpes simplex type 1 virus [304]. So the introduction of a $5^{\prime}-\mathrm{CH}_{2} \mathrm{NH}_{2}$ group brings high specificity of antiviral activity but with a concomitant restriction of spectrum of activity and potency.

The 'parent' compound mentioned above, 5-trifluoromethyl-2'-deoxyuridine (trifluorothymidine; LXII; $\mathrm{R}=\mathrm{CF}_{3}, \mathrm{R}^{\prime}=\mathrm{OH}$ ) had been tested clinically in 1970 and 1971 as an anticancer agent but was withdrawn because of high toxicity and little clinical effect. Its anti-herpes activity was excellent when applied topically. It was more active than IUdR, BrUdR or Ara-C in the rabbit eye herpes keratitis, and in a double-blind clinical study of human ocular herpes infection produced a higher incidence of complete clearing of the infection than IUdR and less toxicity to the corneal epithelium [305]. Its effectiveness is such that it has recently been approved in the USA for general use in ocular herpetic infections [306]. In spite of its known systemic toxicity in humans, successful investigations into the treatment of mouse herpes encephalitis have been carried out using intracerebral dosing at $100 \mathrm{mg} / \mathrm{kg}$ [307]. The mode of action of trifluorothymidine, studied by Heidelberger [308], is that it is preferentially incorporated into viral DNA in place of thymidine, causing a DNA to be formed which is considerably smaller than normal. This DNA incompletely codes for late messenger RNA leading to defective virus coat proteins and thus incomplete virus particles.

Russian workers have reported on the activity of a thymidine analogue fluorinated at the $5^{\prime}$-position ( $\mathrm{LXII} ; \mathrm{R}=\mathrm{CH}_{3}, \mathrm{R}^{\prime}=\mathrm{F}$ ) against vaccinia virus [309] and herpes virus [310], although this compound was reported by Cheng [311] to reduce herpes growth by only $20 \%$ at $400 \mu \mathrm{M}$.

5-Iodo and 5-bromodeoxycytidine (LXIII; $\mathrm{R}=\mathrm{I}, \mathrm{Br}$ ) have selective activity at 
10 and $100 \mu \mathrm{g} / \mathrm{ml}$ against herpes simplex and varicella zoster in vitro, producing only minimal effects on the growth of tissue culture cells (human embryo lung) at $100 \mu \mathrm{g} / \mathrm{ml}[312,313]$. The authors conclude that varicella zoster induces a pyrimidine deoxyribonucleoside kinase which has very high affinity for the 5-halogenated deoxycytidines [314].<smiles>[R]c1cn(C23CC(O)C(O2)C(CO)C3)c(=O)nc1N</smiles>

LXIII<smiles>O=c1ccn(C23CCCC(C2)C3(O)CO)c(=O)[nH]1</smiles>

LXIV<smiles></smiles>

LXV

A series of Japanese patents claim antiviral and antitumour activity for uracil attached to a $2^{\prime}$-halogenated deoxyribose (LXIV) [315] and for 5-fluorouracil and other 5-substituted uracils attached to the 2 -position of tetrahydrofuran (LXV) [316, 317].

\subsection{Other 5-substituted pyrimidines}

Large numbers of non-halogenated deoxyuridine derivatives have been synthesized and tested for anti-herpes activity. Some have very high activity and have sufficiently good clinical properties for general use in herpetic keratitis, e.g. 5-ethyl deoxyuridine (LXVI, $R=E t, R^{\prime}=H$ ). Some of the more recent preparations are listed below:

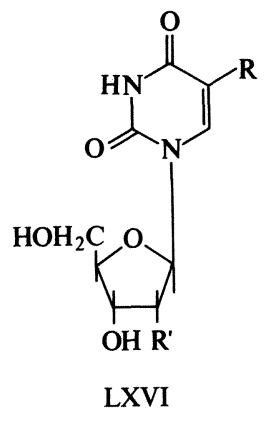

$$
\begin{aligned}
& \mathrm{R}=\mathrm{SCN}, \mathrm{R}^{\prime}=\mathrm{H}, \mathrm{OH} \\
& \mathrm{R}=\mathrm{CH}_{2} \mathrm{O}-\mathrm{H}, \mathrm{Me}, \mathrm{Et}, \mathrm{Pr}, \mathrm{Bu}, \mathrm{CH}_{2} \mathrm{Ph} \\
& \mathbf{R}^{\prime}=\mathrm{H} \\
& \mathbf{R}=\mathrm{Et}, \mathbf{R}^{\prime}=\mathbf{H} \\
& \mathrm{R}=\mathrm{Et}, \mathrm{CH}_{2}=\mathrm{CH}-, \mathrm{R}^{\prime}=\mathrm{H} \\
& \mathrm{R}=\mathrm{CH}_{2} \mathrm{SH}, \mathbf{R}^{\prime}=\mathbf{H} \\
& \left.\begin{array}{l}
\left.\mathrm{R}=\mathrm{Et}, \mathrm{Pr}, \mathrm{CH}_{2}=\mathrm{CH}-, \mathrm{CH}_{2}=\mathrm{CH}-\mathrm{CH}_{2}-\quad\right\} \\
\mathrm{R}^{\prime}=\mathrm{H}
\end{array}\right\} \\
& \mathrm{R}=\mathrm{CH} \equiv \mathrm{C}-, \mathrm{R}^{\prime}=\mathrm{H} \\
& \mathrm{R}=\mathrm{CN}, \mathrm{R}^{\prime}=\mathrm{OH}, \mathrm{H}
\end{aligned}
$$

\subsection{Isoprinosine}

The complex (LXVII) shown below between inosine and the N,N-dimethylamino-2-propanol salt of p-acetamido benzoic acid has been studied since 
about 1969 under the name of isoprinosine or, more recently, inosiplex. It has had a chequered history as an antiviral agent. Early papers claimed that it was effective against influenza, rhinovirus, polio, measles, mumps, chickenpox and herpes infections [326-328]. Very high doses of drug, up to $1,200 \mathrm{mg} / \mathrm{kg}$ but more usually $500-800 \mathrm{mg} / \mathrm{kg}$, were given in mouse experiments coupled with very low virus challenges of $1-4 \mathrm{LD}_{50}[327,329]$. Hamsters were afforded protection against herpes simplex types 1 and 2 in a dose-related manner up to $1,260 \mathrm{mg} / \mathrm{kg}$ when only $12 \%$ animals died compared with $72 \%$ of untreated controls. A virus challenge of $1.5 \mathrm{LD}_{50}$ was used, but no protective effects were seen with $15 \mathrm{LD}_{50}$ [330]. Evidence was presented in this paper for alteration of the metabolism of host ribosomes by the drug. More recent reports have stressed that isoprinosine functions by stimulating immune responses of the host to virus or other infection [331, 332], and its activity has been compared with that of levamisole [218]. An apparent therapeutic effect of isoprinosine on human rhinovirus infection was recorded in a double-blind trial in which some volunteers were given drug $(4 \mathrm{~g} /$ day in divided doses for 7 days) at the time of infection and some 48 hours after infection [333]. Again, a very low virus challenge of 3 TCID $_{50}$ was used.<smiles>O=c1[nH]cnc2c1ncn2C1OC2COC1C(O)C2O</smiles><smiles>C[C@@H](O)CN(C)C</smiles><smiles>CC(=O)Nc1ccc(C(=O)[O-])cc1</smiles>

LXVII

On the other hand in vitro and in vivo studies by various independent groups have concluded that isoprinosine is not active. An extensive study by Glasgow and Galasso [334] in 11 different virus infections in vitro and in vivo using protocols from experiments reported to show activity in isoprinosine, gave no positive results whatever. Similar results were obtained by a German group [335], while two double-blind clinical trials against rhinovirus in human volunteers [336, 337] and one against influenza A (H3, N2) Hong Kong [338] showed no significant protective effects.

I am certain that the controversy about antiviral activity in isoprinosine will continue for some years, but as more sophisticated methods are developed for investigating cell-mediated immunity and its stimulation, answers may be found to some of the questions raised in present day investigations of the action of isoprinosine [339]. The great advantage that isoprinosine has in its favour is that it is very non-toxic even at doses of several grams per day. 
Only two types of amidine have been reported on in this review period. A Japanese group has been studying $\mathrm{N}$-disubstituted benzamidines of general formula (LXVIII) for several years. These were chosen as the most promising group from 280 amidines screened against influenza, and have given rise to two patents [340] and a report on their mode of action [341], which was a combination of rather weak antiviral activity and a therapeutic prevention of lung consolidation in mice. This latter effect was found even when dosing was delayed until 3 days after infection. The preferred compounds were LXVIII, $\mathrm{R}_{1}=\mathrm{H}, \mathrm{R}_{2}=\mathrm{n}$-propyl, $\mathrm{R}_{1}=\mathrm{H}, \mathrm{R}_{2}=$ allyl and $\mathrm{R}_{1}=\mathrm{p}-\mathrm{CH}_{3}, \mathrm{R}_{2}=\mathrm{n}$-butyl. Incorrect formulae are given in the paper.

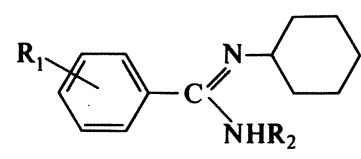

LXVIII<smiles>[R16]Cc1ccc(C(=N)N[R16])cc1</smiles>

LXIX

The other group are also benzamidines, of formula (LXIX) in which $\mathrm{R}_{1}$ and $R_{2}$ are alkyl groups of more than 12 carbon atoms and $R_{3}$ is $H$ or a great variety of alkyl or aryl substituents. Activity is claimed against encephalomyocarditis virus in mice and some compounds are interferon inducers in mice [342]. They are closely related to the phenylene dimethylene diamine interferon inducers (VIII) [112].

Guanidine and its derivatives have, on the other hand provided considerable interest. A most comprehensive review of the action of guanidine against<smiles>CCCC(C)=NC(=N)N</smiles>

LXX<smiles>N=C(N)Nc1ccc(C(=O)Oc2ccc([N+](=O)[O-])cc2)cc1</smiles>

LXXI

picornaviruses has been written by Caliguiri and Tamm [343]. Poliovirus inhibition by guanidine has been studied intensively to try to discover a precise mode of action. It is known to bind to poliovirus RNA and thus impede replication which then results in synthesis of anomalous proteins unable to be incorporated into infective virions [344]. However, the guanidinesensitive process is more complex than this since guanidine is most effective in inhibition of polio at 2-3 hours after infection of cells. If present only from 0 to 2 hours it has much less effect on later growth of virus [345]. The effect of guanidine on foot-and-mouth disease virus is temperature dependent [346]. Guanidine, aminoguanidine or 1-(s-butylideneamino) guanidine (LXX) are claimed to have activity against a wide range of RNA and DNA viruses when dosed to animals in extremely small amounts (250 pg to $250 \mu \mathrm{g} / \mathrm{kg}$ ) [347]. The results so far seen do not appear convincing and parallel those reported under thiosemicarbazones [198]. 
p-Guanidinobenzoic acid phenyl esters of type (LXXI) have been known for some time as inhibitors of trypsin but recently they have been claimed as antiviral agents inactivating Sindbis virus and other enveloped viruses [348, 349].

The guanidine derivatives of most interest have been a series of disubstituted guanidines in which one substituent was a phenyl or substituted phenyl group, having high activity and low toxicity in vitro against the majority of strains of rhinovirus. Four structural types have been reported:

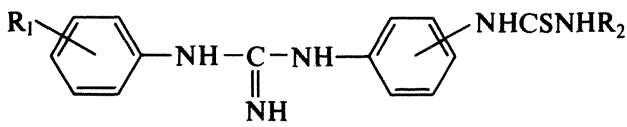

LXXII<smiles>[R]c1cccc(NC(=N)N[C@H]2C[C@H]3C=C[C@H]2C3)c1</smiles>

LXXIV<smiles>[R]NC(=N)Nc1ccc(NC(=O)Nc2ccccc2)cc1</smiles>

LXXIII

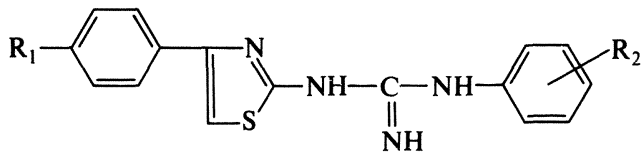

The guanidinothioureas (LXXII) could be substituted with a wide variety of $R_{1}$ and $R_{2}$ groups retaining high antiviral activity. The compound ICI 65709 (LXXII; $\mathrm{R}_{1}=\mathrm{p}-\mathrm{Cl}$, meta-thiourea, $\mathrm{R}_{2}=\mathrm{iBu}$ ) was examined in detail. It was active against 25 different rhinovirus strains in vitro at concentrations between 0.05 and $0.4 \mu \mathrm{g} / \mathrm{ml}, 50 \%$ toxic at $6.0 \mu \mathrm{g} / \mathrm{ml}$, when tested in human embryo lung cells. If other cell types were used, e.g. KB or HeLa, then no activity could be demonstrated. However, in fragments of human embryonic trachea $1.0 \mu \mathrm{g} / \mathrm{ml}$ of drug inhibited rhinovirus growth by $90 \%$. Activity was not confined to rhinoviruses as Echo, Coxsackie, vaccinia, herpes, Semliki forest and Sindbis viruses were also inhibited at drug concentrations $\leq 1.0 \mu \mathrm{g} / \mathrm{ml}$. Coronavirus, influenza, parainfluenza, equine rhinovirus and pseudorabies were not inhibited. While guanidine tested in vitro gives rise to drug-resistant strains very rapidly, this could not be demonstrated with ICI 65709 , neither could its action be reversed by compounds such as ethanolamine or methionine which reverse the action of guanidine [350].

Development of the above compounds led to the ureidoguanidines (LXXIII) which, lacking the thiourea group, were less likely to show thyroid toxicity. The occurrence of antiviral activity as $R_{1}$ and $R_{2}$ were varied was unpredictable and much less frequent than in the earlier series. However, activity was shown against every rhinovirus strain tested and also against coronavirus , which is also a cause of the common cold syndrome. The earlier series was not active against coronavirus. Activity was in the range $0.2-1.6 \mu \mathrm{g} / \mathrm{ml}$ against all strains with a $50 \%$ cellular toxicity being shown at $30 \mu \mathrm{g} / \mathrm{ml}$. The compound of choice was again $\mathrm{R}_{1}=\mathrm{p}$-Cl, meta-guanidine, $\mathrm{R}_{2}=\mathrm{iBu}$ (ICI 73602), which 
virtually eliminated rhinovirus replication in fragments of human embryonic trachea when they were treated for only 1 minute/day with $0.35 \mathrm{mg} / \mathrm{ml}$ or for 5 seconds/day with $0.8 \mathrm{mg} / \mathrm{ml}$. Attempts to make rhinovirus resistant to ICI 73602 were unsuccessful. The compound was about to be taken to a clinical trial [351]. An in vitro comparison of this compound with 3 other antirhinovirus compounds was reported from the Common Cold Research Unit, Salisbury, England [205], but the in vivo results were not given.

The third type of guanidine with antirhinovirus activity (LXXIV) is reported only in a patent. Activity is claimed against rhinovirus strains at concentrations of $\leq 5.0 \mu \mathrm{g} / \mathrm{ml}$ without observable toxicity to cell cultures. A variety of substituents in the aromatic ring can be tolerated and the norbornenyl group can be replaced with several other alicyclic ring systems [352].

Finally, the thiazolylphenylguanidine (LXXV; $R_{1}=R_{2}=H$ ) was the compound chosen by the Lederle group as a clinical trial candidate from a series in which $\mathrm{R}_{1}=\mathrm{H}, \mathrm{Cl} ; \mathrm{R}_{2}=\mathrm{H}, \mathrm{Cl}, \mathrm{F}$, alkyl, carboxylic acid or ester [353]. It was active against 41 different rhinovirus strains at $0.2-1.6 \mu \mathrm{g} / \mathrm{ml}$, but intranasal administration to human volunteers prior to and following a rhinovirus challenge had no effect on occurrence, severity or symptoms of illness compared with placebo [354].

Although guanidines have activity against picornaviruses, biguanides have none but are sometimes weakly active against influenza, as evidenced by the early interest in ABOB, N,N-anhydro-bis( $\beta$-hydroxyethyl)-biguanide. N-Phenyl and $\mathrm{N}$-(p-ethoxy)phenyl biguanides have recently been reported active in protecting mice against an influenza A/PR8 infection [355], while hexamethylene bis-(N6-p-chlorophenyl)-biguanide (LXXVI; chlorhexidine) a wellknown antiseptic, was highly effective as a virucidal agent against herpes, an enveloped virus. Polio and adenovirus which are not enveloped viruses were not inactivated [356].<smiles>N=C(NCCCNC(=N)NC(=N)Nc1ccc(Cl)cc1)NC(=N)Nc1ccc(Cl)cc1</smiles>

LXXVI

\section{$7 \quad$ Aromatic compounds}

This group contains those compounds which do not conveniently fit into any of the other sections of the review and have one or more aromatic rings in the molecule. These may or may not be the molecular feature associated with antiviral activity.

Russian workers have developed three types of aromatic compounds as antivirals. The most significant group have been naphthoquinones of which 6-bromonaphtho-1,2-quinone (LXXVII; bonaphthone) and 1,2,3,4-tetra-oxo1,2,3,4-tetrahydronaphthalene dihydrate (LXXVIII; oxolin) have become widely available drugs for the prophalyxis of influenza in the USSR. 
<smiles>O=C1C=Cc2cc(Br)ccc2C1=O</smiles>

LXXVII<smiles>O=c1c(=O)c(=O)c2ccccc2c1=O</smiles>

LXXVIII

Quinones were initially investigated in 1966 [357] and were claimed to have activity in vitro against influenza PR8. 1,2-Naphthoquinone and 7-hydroxy1,2-naphthoquinone had particularly high activity at 1.0 and $0.1 \mu \mathrm{g} / \mathrm{ml}$. 6-Hydroxy-1,2-naphthoquinone was much less active than the 7-isomer. Later studies claimed that 2,3-dichlorobenzoquinone was virucidal to influenza virus at $0.1 \mu \mathrm{g} / \mathrm{ml}$ [358] which was perhaps not surprising in view of its high chemical reactivity. Of many quinones tested only (LXXVII) was active in mice against influenza dosed at $62 \mathrm{mg} / \mathrm{kg}$ for 5 days [359]. Clinical trials on volunteers dosed $50 \mathrm{mg}$ b.i.d. from 1 day before to 5 days after infection with influenza reduced morbidity from $78 \%$ in controls to $38 \%$ in treated. No virus isolations or symptom reductions were recorded although serological studies confirmed the prophylactic effect [360, 361]. Many large scale trials assessed by reduction of morbidity have been carried out using most of the influenza $A$ viruses, e.g. [362]. On the other hand a therapeutic trial with doses of 50$100 \mathrm{mg}$ four times per day in 140 'influenza afflicted patients' showed no beneficial effects [363]. In a comparison with 1-(1-aminoethyl)adamantane (rimantadine) in influenza infected mice, rimantadine had good oral activity when dosed at time of infection and also some therapeutic effect dosed after infection but bonaphthone had only slight prophylactic effect and no therapeutic activity. Chick embryo toxicity was $1,000 \mu \mathrm{g} /$ embryo for rimantadine and $10 \mu \mathrm{g} /$ embryo for bonaphthone [364]. It will be interesting to hear of the efficacy of bonaphthone in the current influenza $\mathrm{A}_{0}$ epidemic in Russia.

Oxolin (LXXVIII) was approved for general use against influenza in Russia in 1972 after extensive laboratory and clinical trials. It was used as a $0.25 \%$ ointment applied twice daily to the nasal mucosa for 25 days during the development of an epidemic or on contact with an infected patient [361]. After clinical trials lasting 4 years it was claimed to be highly effective in prophylaxis and treatment of influenza [365]. Tests carried out in our laboratories were unable to detect activity in vitro against influenza $A_{0}$ or $A_{2}$ at non-toxic concentrations with either oxolin or bonaphthone [366].

The second type comprises two halogenated phenols 'tebrophen' (LXXIX) and tri-iodo resorcinol (LXXX).<smiles>Oc1c(Br)cc(-c2cc(Br)c(O)c(Br)c2O)c(O)c1Br</smiles>

LXXIX<smiles>Oc1c(I)cc(I)c(O)c1I</smiles>

LXXX 
Although tebrophen was first reported in 1970 [367], little has been published apart from a patent and a recent paper claiming activity against an arbovirus (Western equine encephalitis) in chick embryo [368]. Arboviruses are a common cause of encephalitic human disease in many parts of the world.

Tri-iodoresorcinol is claimed to be highly effective against herpes simplex skin and eye infections applied topically in an ointment at $0.5-1.0 \%$ concentration. This product is reported to be more active than 5-iodo-2'-deoxyuridine. All reports so far are in patent literature [369] and it would appear to be a virus disinfectant.

The third type is a glyoxal, a group frequently investigated in the past and noted for low toxicity by some in vitro methods and high toxicity by other more sensitive methods, as well as rapid development of resistant strains. 9-Oxo-2-fluorenylglyoxal bisulphite (LXXXI; florenal) has been developed as a drug for topical use in herpes simplex infections [370, 371].

Two series of aryl $\beta$-diketones having activity against equine rhinovirus in tissue culture and monkey trachea, and against influenza in ferret trachea, have been reported by Diana et al: [372]. The first series of 87 compounds were exemplified by (LXXXII) and by analogues having an unbranched saturated linking chain, and benzene substitutions other than methylenedioxy. The compounds were all rather toxic in vitro and activity was shown at between half and one quarter of the toxic level. The best compound of 61 in the second series (LXXXIII; WIN 38020) was active in vitro at $1.5 \mu \mathrm{g} / \mathrm{ml}$, toxic at $6.0 \mu \mathrm{g} / \mathrm{ml}$ against equine rhinovirus, active at $6 \mu \mathrm{g} / \mathrm{ml}$, toxic at $25 \mu \mathrm{g} / \mathrm{ml}$ against herpes simplex. It has been found effective against ocular herpes in the rabbit when applied topically.<smiles>O=CCNc1ccc2c(c1)C(=O)c1ccccc1-2</smiles>

LXXXI<smiles>CCC(=O)C(CC/C(C)=C/CCc1ccc2c(c1)OCO2)C(=O)CC</smiles><smiles>CCC(=O)C(CCOc1ccc(OC)cc1Cl)C(=O)CC</smiles>

A large number of papers reporting activity of $\mathrm{N}$-phenyl- $\mathrm{N}^{\prime}$-aryl or alkyl thioureas against polio [373], rhino [374] and Coxsackie [375] viruses have been published by Galabov. His most active compounds against rhinovirus are: 

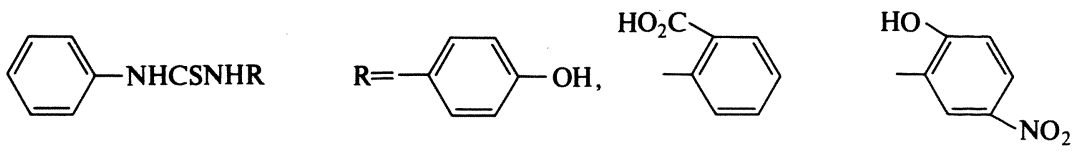

These were tested at their maximum sub-toxic concentrations as determined by lack of effect on the replication of HeLa cells. The p-hydroxyphenyl derivative at $20 \mu \mathrm{g} / \mathrm{ml}$ produced a $1 \mathrm{log}$ reduction of final virus titre 20 hours after infection compared with control, virus growing up exponentially after a lag period 2 hours greater than control. In our laboratories, testing of large numbers of aryl thioureas made as intermediates in our guanidine studies, against rhinoviruses did not produce any active compounds [376].

Polyphenols and tannins are virus inactivators effective against polio, various enteric viruses and herpes. These substances occur in appreciable quantities in grape juice $(3,300 \mathrm{mg} / \mathrm{l})$, red wine $(2,200 \mathrm{mg} / \mathrm{l})$ and white wine $(260 \mathrm{mg} / \mathrm{l})$ and it has been shown that virus inactivation by wine or diluted wine is quite an efficient process. These facts gave the delightful title to the paper - 'Drinkers Rejoice - a Little Wine may Kill your Virus' [377]. This correlates with antiherpes activity found in enzymically oxidized o-diphenols, e.g. pyrocatechol, caffeic acid, chlorogenic acid [378] and flavanoids [379]. Blocking of some of the hydroxyls of naturally occurring flavones by methylation may change antiviral specificity. 4'-Hydroxy-5,6,7,8-tetramethoxyflavone (LXXXIV) has lost anti-herpes activity but has developed moderate activity $(20 \mu \mathrm{g} / \mathrm{ml}$, toxic $100 \mu \mathrm{g} / \mathrm{ml})$ against rhinoviruses [380].<smiles></smiles>

LXXXIV<smiles>[R]=CCC</smiles>

LXXXV

Finally, a series of carbazic acid ester derivatives of a large variety of aryl methyl ketones of which (LXXXV) is an example were claimed in patents to have activity against rhinovirus strains $1 \mathrm{~B}, 2,5,14$ and 23 , but no details of drug concentration or toxicity were given [381].

\section{Inorganic compounds}

Inhibition of RNA-dependent DNA polymerase found in oncornaviruses has been demonstrated in several inorganic complexes containing tungsten and antimony [382]. These are generally called heteropolyanions and in spite of their complexity are stable, water soluble salts. The most studied has been the ammonium salt of 5-tungsto-2-antimoniate (LXXXVI) whose formula has 
recently had to be amended to 9-antimonio-21-tungsto-sodate (LXXXVII) because of the discovery of one sodium atom buried in the 116 atoms of the anion.

$\left[\mathrm{Sb}_{2} \mathrm{~W}_{5} \mathrm{O}_{20}\right]^{4}\left(\mathrm{NH}_{4}\right)_{4}^{+} \mathrm{H}_{2} \mathrm{O}$

LXXXVI
$\left[\mathrm{NaSb}_{9} \mathrm{~W}_{21} \mathrm{O}_{86}\right]^{18-}\left(\mathrm{NH}_{4}\right)_{18}^{+} 8 \mathrm{H}_{2} \mathrm{O}$

It was shown to inhibit mouse leukaemia and sarcoma viruses in vitro and in vivo [383] and encephalomyocarditis and vesicular stomatitis viruses in mice dosed from 25 to $100 \mathrm{mg} / \mathrm{kg}$ i.p. The maximum non-toxic dose in mice was $250 \mathrm{mg} / \mathrm{kg}$ [384]. A curious feature found in this work was that although about $50 \%$ of treated mice survived compared with none in the control group, all mice developed the same virus titres in blood and brain tissue. This indicates that death in these infections may not be directly related to virus titre.

Arising from the interest in this work, claims for antiviral activity in complexes containing palladium [385], platinum [386], rhodium [387], hafnium, zirconium [388] and salts of beryllium (!) [389] have been seen.

Uncomplexed zinc ions have inhibitory effects against several viruses. $0.1 \mathrm{~mm}$ $\mathrm{ZnCl}_{2}$ added to cell cultures infected with rhinovirus gives $99 \%$ reduction of virus replication. The inhibitory action is directed against proteolytic cleavage of high molecular weight proteins synthesized from virus RNA, which are normally cleaved to form virus capsid polypeptides. As a result, the assembly of new virus particles is inhibited. No cellular toxicity was found with $0.1 \mathrm{~mm}$ $\mathrm{ZnCl}_{2}$ [390, 391]. In a similar way $0.1 \mathrm{~mm} \mathrm{ZnCl}_{2}$ gives $95 \%$, and $0.2 \mathrm{~mm}, 99.8 \%$ irreversible inhibition of herpes simplex virus [392, 393]. Also reported is the inhibition of Sindbis virus by $\mathrm{ZnCl}_{2}$ [394].

\section{$9 \quad$ Aliphatic compounds}

Perhaps the simplest organic compound to affect virus replication selectively is phosphonoacetic acid (LXXXVIII), patented in 1971 [395] and reported to inhibit herpes simplex in vitro and in vivo in 1973 [396].<smiles>O=C(O)CP(=O)(O)O</smiles>

LXXXVIII

It binds specifically to the virus DNA polymerase and only affects other DNA polymerases at much higher concentrations [397, 398, 399]. It produces $99.98 \%$ inhibition of herpes simplex strain 1 and strain 2 at $100 \mu \mathrm{g} / \mathrm{ml}$ in vitro and 
fresh isolates from clinical herpes are equally inhibited. However, the remaining $0.02 \%$ of virus is relatively resistant and can be selected out in 4 passages in the presence of $100 \mu \mathrm{g} / \mathrm{ml}$. This resistance is stable and correlates with resistance of the DNA polymerase in these viruses [400, 401]. Phosphonoacetic acid has been found effective against ocular, skin and encephalitic herpes in animals but has not yet been tested in humans. Alford and Whitley have critically reviewed the treatment of human herpes infections [402] and warn against too rapid evaluation of new drugs in life-threatening diseases. Distribution of phosphonoacetic acid in rabbit, dog and monkey has been studied by Bopp [403]. Although its principal action is against herpes virus it has been found highly effective and better than Ara-A at equal doses in cytomegalovirus infections of mice [404], against Epstein-Barr virus in vitro [405, 406] and herpes saimiri of monkeys [407]. Two useful reviews of the actions of phosphonoacetic acid have been written by Overby [400] and Hay [408]. Synthesis and anti-herpes activity of many analogues:<smiles>[R]OC(=O)CP([R])(=O)O</smiles>

$$
\mathrm{R}_{1}=\mathrm{OH}, \mathrm{OCH}_{3}, \mathrm{O}\left(\mathrm{CH}_{2}\right)_{2} \mathrm{CH}_{3}, \mathrm{O}\left(\mathrm{CH}_{2}\right)_{5} \mathrm{CH}_{3}
$$

were reported by Herrin [409]. Only $\mathrm{R}_{1}=\mathrm{OH}, \mathrm{R}_{2}=\mathrm{n}-\mathrm{Pr}$ had activity equal to phosphonoacetic acid itself.

The extracellular virus inactivator calcium elenolate (LXXXIX), active against all viruses tested, active intranasally in hamsters against parainfluenza at $0.75 \%$ concentration and of low toxicity has been reviewed by Renis [410] but no further studies appear to have been done.<smiles>COC(=O)C1=COC(C)C(C=O)C1CC(=O)[O-]</smiles>

LXXXIX<smiles>CC1OC2(CO)OC1(C)C(C)(O)C(O)C2O</smiles>

$\mathrm{XC}$<smiles>CC1(N)C(O)C(O)C2(CO)OC(O)C1C2O</smiles>

$\mathrm{XCI}$

Monosaccharide derivatives have excited some interest as antivirals in the last few years. 2-Deoxy-D-glucose (XC) is a non-specific inhibitor of glycoprotein synthesis in several viruses including influenza, parainfluenza, respiratory syncytial and measles. It is likely to be a competitive inhibitor of glucose and while in vitro this is possible it is not really possible in vivo. This was borne 
out by its inactivity against influenza $\mathrm{A}$ in mice and parainfluenza in hamsters, even though it was used at near-toxic doses [411].

D-Glucosamine (XCI) is also an inhibitor of glycoprotein synthesis but in addition inhibits synthesis of viral RNA without affecting host cell RNA synthesis. This is achieved by reducing the cellular pool of uridine triphosphate to a level at which, because of the different affinities of the RNA polymerases, the virus polymerase cannot use it and the cell polymerase can [412]. Possibly because of this second mode of action D-glucosamine has been reported to have in vivo activity in mice infected with influenza. Similar i.p. dosing of mice infected with Rous sarcoma virus produces a decreased rate of tumour growth [413].

6-Amino-6-deoxy-D-glucose, an analogue of D-glucosamine is also active in vivo in the prophylactic treatment of influenza in mice [414], while N-carbobenzoxy-D-glucosamine inhibits Echo 12, a non-enveloped virus of the picornavirus group, in vitro [415].

Another basic glucose derivative 1,2-O-isopropylidene-3-O $\left(3^{\prime}-\mathrm{N}, \mathrm{N}\right.$-dimethylamino-n-propyl)-D-glucofuranose (XCII) is active against influenza A, rhinovirus, mumps and herpes virus [416, 417]. Its in vivo activity against herpes and the respiratory viruses is sufficiently good for clinical trials to be starting against the former and expected against the latter in 1977 [418].

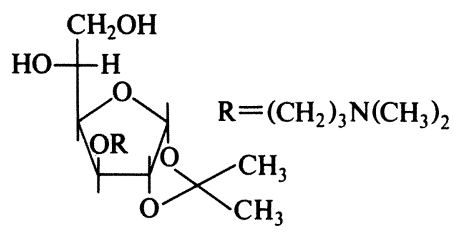

$\mathrm{XCII}$

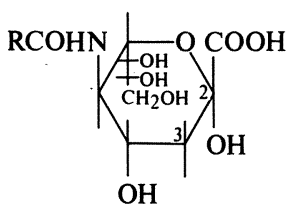

XCIII

It has long been considered that inhibitors of the enzyme neuraminidase present on the surface of influenza and parainfluenza viruses might prove to be useful antiviral drugs. N-Acetylneuraminic acid (XCIII; $\mathrm{R}=\mathrm{CH}_{3}$ ) present on the surface of all cells as the terminal sugar of a glycoprotein, is cleaved at its glycosidic linkage at $\mathrm{C}-2$ oxygen by neuraminidase. The close analogue (XCIII; 2,3-dehydro, $\mathrm{R}=\mathrm{CF}_{3}$, Fana) is an effective inhibitor of the enzyme and also inhibits influenza replication in vitro [419], but does not have any effect in vivo in mice [420].

Whether ascorbic acid has any effect in the prevention of rhinovirus infections or not is still hotly debated. Linus Pauling has as his supporters many people who take several grams of vitamin $\mathrm{C}$ each day and assert that they never catch colds. However, numerous small scale clinical trials have not shown any positive effects, e.g. [421]. Some large scale trials against a wide variety of natural infections showed minor positive effects [422, 423] but another large scale trial showed no effect [424]. 


\section{Amino acids and peptides}

Very little has been found in this area of chemistry to be of value in antiviral chemotherapy. Perhaps the most significant were carbobenzoxy-di- and tripeptides which had specific anti-measles virus activity:

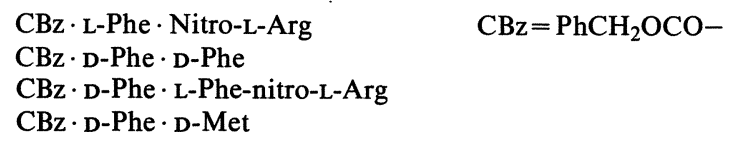

Several others were prepared and tested, all containing carbobenzoxy L- or D-phenylalanine. They were very non-toxic and gave antiviral levels of drug in the serum of animals dosed orally [425, 426]. One of their modes of action is to inhibit the penetration of virus into cells, $1 \mu \mathrm{g} / \mathrm{ml}$ of the third peptide in the list being sufficient to achieve this in Vero cells [427]. The effect of this compound and 21 other peptides on measles virus-specific haemolysis and infectivity has also been studied [428].

Two examples of work which may be interesting from an academic viewpoint but totally inappropriate in the search for useful drugs, are activities against influenza replication in vitro discovered in $a$-amanitin, the extremely toxic polypeptide from amanita phalloides the death-cap mushroom, which is an RNA virus polymerase inhibitor [429], and in Mannich bases derived from highly carcinogenic $\beta$-naphthylamine, formaldehyde and a variety of amino acids including alanine, leucine, methionine and $\beta$-alanine [430, 431].

Poly-lysine and poly-arginine have been mentioned earlier as enhancers of the interferon inducing activity of poly (rI: rC) (p. 271 and [44, 45]). Lysine analogues (XCIV) and (XCV) have been studied for antiviral activity [432, 433].<smiles>NCCCCC(N)C(=O)O</smiles>

XCIV<smiles>NOCCC(N)C(=O)O</smiles>

XCVI

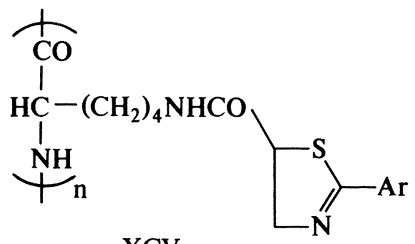

$\mathrm{XCV}$<smiles>N=C(N)NC(=O)NC(N)CCC(=O)O</smiles>

XCVII

Canaline (XCVI), a structural analogue of ornithine inhibits vaccinia virus replication at both an early and a late stage of the process. The activity is reversed by addition of ornithine [434]. The arginine analogue glutamyl guanidine (XCVII) also has antimetabolic and antiviral activity [435], and 
arginine itself has been reported to cause inhibition of a viral tumour in animals [436].

\section{$11 \quad$ Natural products}

\subsection{Epipolythiodiketopiperazines}

This group of compounds are probably better known as gliotoxin analogues, since gliotoxin (XCVIII) was the first of the series to be discovered.<smiles>CN1C(=O)C23CC4=CC=CC(O)C4N2C(=O)C1(CO)SS3</smiles>

XCVIII<smiles>[R]N1C(=O)C2N(C)C(=O)C1N2[R]</smiles>

XCIX

About 10 members of the group have so far been identified all containing the epipolythiodiketopiperazine nucleus (XCIX). Since the number of sulphur atoms in the bridge can vary from 1 to 4 but is most frequently 2 , each member can form a small family of very closely related compounds. All have activity against RNA viruses as a consequence of irreversible inhibition of viral RNA polymerase. Activity is usually very high. The simple nucleus (XCIX; $\mathrm{R}_{1}=\mathrm{R}_{2}=\mathrm{CH}_{3}, \mathrm{n}=2$ ) was the most active, inhibiting Coxsackie A21 viral RNA synthesis by $50 \%$ at $0.0003 \mu \mathrm{g} / \mathrm{ml}$. The concentration required to inhibit host cell RNA synthesis by $50 \%$ was $5 \mu \mathrm{g} / \mathrm{ml}$, a selectivity of $1.6 \times 10^{4}$. Activity against rhinovirus strains was shown at $0.06 \mu \mathrm{g} / \mathrm{ml}$ with a selectivity of 4 [437]. The most widely investigated compounds were aranotin $(C, R=H)$ and acetylaranotin $\left(\mathrm{C}, \mathrm{R}=\mathrm{COCH}_{3}\right)$. They were highly active against rhinoviruses and a wide range of other RNA viruses in vitro. In mice, aranotin was active against Coxsackie $\mathrm{A} 21$ with an $\mathrm{ED}_{50}$ of $0.125 \mathrm{mg} / \mathrm{kg}$ i.p. The small family of aranotins is produced by fermentation of Aspergillus terreus [438].

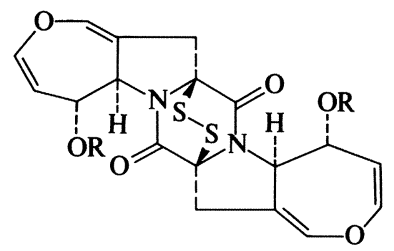

C

Chemical modifications of acetylaranotin have been reported by Murdock [439]. It was soon evident that the principal source of activity of these compounds was the disulphide bridge, or the possibility of forming it from free $\mathrm{SH}$ 
groups. If the $\mathrm{SH}$ groups were alkylated or protected by groups not readily hydrolyzed, then all activity was lost. The interaction of these natural products with the synthesis of viral RNA polymerase must involve this reactive $S-S$ bridge in irreversible thiolation.

Other members of this group are apoaranotin [438], sporidesmin [440], chaetocin [441], chaetomin [442], verticillin [443], sirodesmin [444] and hyalodendrin [445]. The last two are the most recentiy discovered. Sirodesmin A (CI) is the major component of a family of 10 closely related compounds formed on fermentation of Sirodesmium diversum. It has very high activity against rhinoviruses in vitro (active at $0.01 \mu \mathrm{g} / \mathrm{ml}$, not toxic at $0.4 \mu \mathrm{g} / \mathrm{ml}$ ) and in fragments of human embryonic trachea, and has relatively low toxicity to animals [446]. The structures of other sirodesmins and the $\mathrm{X}$-ray analysis of sirodesmin A have been reported [447].

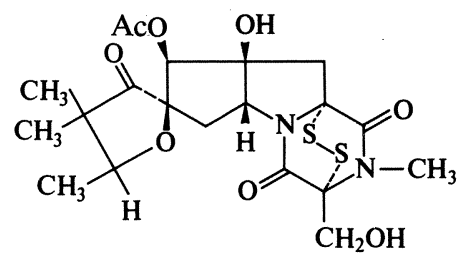

CI<smiles>CN1C(=O)C2(Cc3ccccc3)SSC1(CO)C(=O)N2C</smiles>

CII

Hyalodendrin A (CII) was reported almost simultaneously from three different sources, Penicillium turbatum [448], a Torula species [445] and a Hyalodendrin species [449]. Again there is a family of $2 \mathrm{~S}, 3 \mathrm{~S}, 4 \mathrm{~S}$ and bis-Smethyl compounds, but only the S-bridged compounds show activity against polio and Coxsackie viruses. The $\mathrm{LD}_{50}$ for mice is $40 \mathrm{mg} / \mathrm{kg}$.

Synthesis of analogues of these molecules has given (CIII), a dehydroanalogue of gliotoxin, which inhibits RNA-dependent DNA polymerase from oncogenic RNA viruses at $13 \mu \mathrm{g} / \mathrm{ml}$ [450]. The very similar (CIV) which has an $-\mathrm{S}-\mathrm{CH}_{2}$ bridge is completely inactive [451].<smiles></smiles>

CIII<smiles>CC1(C)c2ccccc2N1C(=O)N1C2CCC1(C(C)(C)C)C(=O)C2</smiles>

CIV

\subsection{Rifamycins}

The family of antibacterial antibiotics known as rifamycins are produced by fermentation of Streptomyces mediterranei. Chemical modification of the 
natural product led to the highly active rifampin (CV) which in 1969 was discovered to have activity against pox viruses $[452,453]$.

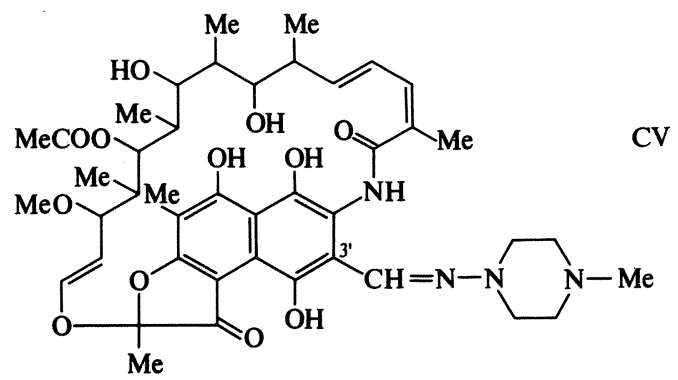

Inhibition of vaccinia virus is apparent at $60-100 \mu \mathrm{g} / \mathrm{ml}$ in vitro and is probably specific for the virus although the evidence is not altogether conclusive. Rifampin and its analogues were thoroughly reviewed by Moss [454] and Silvestri [455, 456]. Claims for activity against herpes virus [457], cytomegalovirus [458] and oncornaviruses [459] in vitro have been reported for rifampin and numerous derivatives which differ in the 3 -side chain. When rifampin and its analogues are tested in vitro against virus infections, a time period of 2-3 days has to elapse before the full antiviral effects are apparent and even then, if the drug is removed, virus replication resumes vigorously. In view of this and the high concentrations required in vitro very little animal testing and even less in humans has been attempted. The possibility that these compounds might inhibit tumour growth in animals is being examined [459].

\subsection{Other natural products}

Many hundreds of preparations from natural sources, some crude, some partially and some completely purified, are claimed to possess antiviral activity. Some are amenable to elegant elucidation of a complex chemical structure and can then be modified in the search for higher activity or lower toxicity, while others, like milk, will probably remain an unsolved problem for many years. Human and cow's milk have in vitro activity against several viruses, particularly influenza A/57 and influenza B/Taiwan. The observed activity is not due to the lysozyme, lactoferrin or IgA known to be present. Fresh human milk is very active and may be important in protecting babies from enteric virus disease. It loses about $50 \%$ of its activity on boiling or storing at $-20^{\circ} \mathrm{C}[460]$.

Some interfere fundamentally with normal cell functions and antiviral action is measured with little reference to these other actions of the compound. An example of this is the anti-herpes virus activity of cytochalasin B at 10-100 $\mu \mathrm{g} / \mathrm{ml}$ [461]. This compound is a complex glycopeptide of known structure which at $10 \mu \mathrm{g} / \mathrm{ml}$ causes the extrusion of nuclei from cells and at $1 \mu \mathrm{g} / \mathrm{ml}$ prevents cytoplasmic division resulting in multinucleate cells. 9-Methyl strep- 
timidone (CVI) is a secondary metabolite of Streptomyces species S-885 and is toxic to HeLa cells and rabbit kidney cells at $0.2 \mu \mathrm{g} / \mathrm{ml}$, but in these cells has anti-polio virus activity at $0.02 \mu \mathrm{g} / \mathrm{ml}$. In spite of its high cellular toxicity the acute $\mathrm{LD}_{50}$ in mice is $280 \mathrm{mg} / \mathrm{kg}$ by i.p. injection [462]. Mice are afforded protection against a low challenge $\left(5 \mathrm{ID}_{50}\right)$ of influenza $\mathrm{A} 2$ if dosed three times with $20 \mathrm{mg} / \mathrm{kg}$ before infection, at 1 hour and 3 hours after infection and then once daily for 4 days. A single i.p. injection of $5 \mathrm{mg} / \mathrm{kg} 2$ hours before infection gave $20 \%$ protection and on the basis of this observation, interferon was looked for and found in the lungs and serum of the mice [463].<smiles>C/C=C\C(C)=C/C(C)C(=O)CC(O)CC1CC(=O)NC(=O)C1</smiles>

CVI<smiles>CC1(C)C(O)CC[C@@]2(C)[C@@H]3C[C@H](CO)[C@@H](O)C[C@H]3CC[C@@H]12</smiles>

CVII

In aphidicolin (CVII) toxicity was not apparent until careful metabolic studies had been carried out. The compound, derived from cultivation of Cephalosporium aphidicola, gave $50 \%$ inhibition of herpes simplex strains 1 and 2 at $0.2 \mu \mathrm{g} / \mathrm{ml}$, and of vaccinia at $0.4 \mu \mathrm{g} / \mathrm{ml}$. It was not visibly toxic to confluent human embryo lung cells used in the test at $200 \mu \mathrm{g} / \mathrm{ml}$, but when the biosynthesis of cell components was investigated, although there was no inhibition of RNA and protein synthesis, cellular DNA synthesis was inhibited by $50 \%$ at $0.2 \mu \mathrm{g} / \mathrm{ml}$ identical with the antiviral level. Thus there was no therapeutic ratio. Aphidicolin was as effective at $10 \mathrm{mg} / \mathrm{ml}$ as IUdR at $1 \mathrm{mg} / \mathrm{ml}$ in herpes keratitis in the rabbit eye and was equally effective against IUdR resistant strains [464].

Two natural products have been used in actual treatment of acute viral hepatitis, silymarin (CVIII) [445] and cyanidol (CIX) [466]. Both appear to protect the liver in some non-specific way since silymarin also protects against liver damage by chlorinated hydrocarbons. Since hepatitis virus cannot yet be grown in vitro it is not known whether the compounds inhibit virus replication.<smiles>COc1cc(C2Oc3ccc(C4Oc5cc(O)cc(O)c5C(=O)C4O)cc3OC2CO)ccc1O</smiles>

CVIII<smiles>Oc1cc(O)c2c(c1)OC(c1ccc(O)c(O)c1)[C@H](O)C2</smiles>

CIX 
From the leaves of Ophiorrhiza mungos can be extracted camptothecin (CX; $\mathrm{R}=\mathrm{H})$ and 10-methoxy camptothecin $\left(\mathrm{CX} ; \mathrm{R}=\mathrm{OCH}_{3}\right)$ which are antitumour and antileukaemic agents. At $0.02 \mu \mathrm{g} / \mathrm{ml}$ they inhibit completely the formation of herpes virus plaques in tissue culture and give $80 \%$ inhibition at $0.01 \mu \mathrm{g} / \mathrm{ml}$. Although there is no visual toxicity to confluent cell monolayers at $100 \mu \mathrm{g} / \mathrm{ml}$, the compounds will fragment DNA in growing cultures at low concentration [467].<smiles>[X][X]c1cccc2nc3c(cc12)Cn1c-3cc2c(c1=O)COC(=O)C2(O)CC</smiles>

Unidentified antiviral substances have been extracted from marine algae [468] and the bacterium Streptococcus faecalis [469]. A mushroom Lentinus edodes produces an antiviral polysaccharide active against influenza [470] - recently shown to contain fungal virus double-stranded RNA [69, 70], and a streptomyces species produces neuraminin, a neuraminidase inhibitor of unknown structure [471].

\section{Conclusion}

The clinically successful antiviral agents are still pitifully few, although the few have helped to prevent, ameliorate or cure diseases which might otherwise be fatal. Ara-A stands out among the nucleotide analogues as having most promise for herpetic diseases. Upper respiratory virus infections seem notoriously difficult to prevent as some very promising compounds have been sent to clinical trial without effect. Breakthroughs will, no doubt, come - the prospects for interferon look much brighter now than they did 7-10 years ago - and we may have novel vaccines in a few years time for influenza and herpes which will be effective against any new serotypes and longer lasting than the present ones. It seems very doubtful whether effective vaccines will ever be produced for rhinovirus, Coxsackie or adenovirus infections and others where there are many different serotypes, and these diseases will continue to present a formidable challenge to antiviral chemotherapy.

One ought to mention here the unprecedented success achieved by the World Health Organization in 1977 in eliminating smallpox, principally by vaccination. There are no longer any foci of endemic smallpox anywhere in the world and for the first time in history, a disease has been eradicated.

Perhaps, one day in the future, given the combined skills of virologists, biochemists and chemists working together on disease targets, one might be able to say the same of another virus disease. 


\section{References}

1 R.G. Smith and R.C. Gallo: Biochem. Pharmac. 25, 491 (1976).

2 F.M. Schabel, Jr.: Cancer Chemother. Rep. Part 1, 59, 261 (1975).

3 R.C. Gallo, R.E. Gallagher, R.G. Smith, D.H. Gillespie and A.M. Wu: Prog. Chemother. 3, 28 (1974) (Antibact. Antivir. Antineopl.), Proc. 8th Int. Congr. Chemother., 1973.

4 D.J. Bauer: Br. med. J. 3, 275 (1973).

5 T.H. Maugh II: Science 192, 128 (1976).

6 D.L. Swallow: Prog. Med. Chem. 8, 119 (1971).

7 C.E. Hoffmann: Ann. Rep. Med. Chem. 11, 128 (1976).

8 S. Baron and G. Galasso: Ann. Rep. Med. Chem. 10, 161 (1975).

9 Y. Becker: Israel J. Med. Sci. 11, 1135 (1975).

10 J. G. Tilles: Ann. Rev. Pharmac. 14, 469 (1974).

11 A. Andreani, V. Cavrini, G. Giovanni, A. Manninip and L. Franchi: Farmaco, Ed. sci. 30, 440, 568 (1975).

12 W.A. Carter: Selective Inhibitors of Viral Functions, pp. 377. Chemical Rubber Co. Press, Cleveland, Ohio, 1973.

13 G.N. Pershin: Farmak. Toks. 38, 517 (1975).

14 Y. Becher: Monographs in Virology: Antiviral Drugs: Mode of Action and Chemotherapy of Viral Infections of Man, pp. 144. Springer Verlag, Wien and New York 1976.

15 B. B. Williams: J. Am. Osteop. Ass. 76, 585 (1977).

16 R.W. Sidwell: Chemother. infect. Dis. 1976, p. 31.

17 J.H. Thompson: Essent. Pharmac., 2nd ed., p. 528 (1976).

18 G.D. Diana: Angew. Chem. 88, 458 (1976).

19 J.P. Luby, J. M. Tracy and S. R. Jones: Ann. Rev. Med. 25, 251 (1974).

20 H.E. Kaufman: Symp. Ocul. Ther. 6, 49 (1973).

21 Yu.F. Maichuk: Prog. Chemother. 2, 968 (1974).

22 R. B. Couch and G. G. Jackson: J. infect. Dis. 134, 516 (1976).

23 C. J. Pfau: Bull. WHO 52, 737 (1975).

24 E.C. Herrmann, Jr.: Ann. N.Y. Acad. Sci. 284, 1-720 (1977).

25 S. Baron, N.B. Finter, G.J. Galasso, L.A. Glasgow, H.B. Levy and J.S. Younger: Science 180, 779 (1973).

26 M. Ho and J. A. Armstrong: Ann. Rev. Microbiol. 29, 131 (1975).

27 D. C. Burke: Sci. Am. 236, 42 (1977).

28 G. Bodo: Z. physiol. Chem. 357, 121 (1976).

29 I. Gresser and M.C. Tovey: German Pat. 2,461,379 (1974).

30 K. Cantell, H. Strander, G.Y. Hadhazy and H.R. Nevanlinna: The Interferons, p.223. Ed. G. Rita. Academic Press, New York 1968.

31 N.B. Finter, private communication.

32 R. Weil and F. Dorner, in: Selective Inhibitors of Viral Functions, p. 107. Ed. W.A. Carter. Chemical Rubber Co. Press, Cleveland, Ohio, 1973.

33 W. K. Joklik: Ann. N.Y. Acad. Sci. 284, 711 (1977).

34 M.J. Clemens, in: Chemoprophylaxis and Virus Infections of the Respiratory Tract, vol.II, p. 180. Ed. J.S. Oxford. Chemical Rubber Co. Press, Cleveland, Ohio, 1977.

35 G. Emodi, T. Rufli, M. Just and R. Hernandez: Scand. J. infect. Dis. 7, 1 (1975).

36 G.W. Jordan, R.P. Fried and T.C. Merigan: J. infect. Dis. 130, 56 (1974).

37 T.C. Merigan, T.S. Hall, S.E. Reed and D. A. Tyrrell: Lancet 1973, 564.

38 R. Sundmacher, D. Neumannh and K. Cantell: Von Graefes Arch. Klin. Ophthalmol. 201, 39 (1976).

39 R.T. Emond, B. Evans, E.T. Bowen and G. Lloyd: Br. med. J. 2, 541 (1977).

40 K. Cantell: Med. Biol. 55, 69 (1977).

41 A. Isaacs: Aust. J. exp. Biol. Sci. 43, 405 (1965).

42 G.P. Lampson, A.A. Tytell, A.K. Field, M.M. Nemes and M.R. Hilleman: Proc. nat. Acad. Sci., USA 58, 782 (1967). 
43 A.K. Field, in: Selective Inhibitors of Viral Functions, p. 150. Ed. W.A. Carter. Chemical Rubber Co. Press, Cleveland, Ohio, 1973.

44 H. B. Levy, W. London, D. A. Fuccillo, S. Baron and J. Rice: J. infect. Dis. 133, suppl. June, A256 (1976).

45 E. L. Stephen: U.S. Ntis. Ad. Rep., Issue AD AO26158, p.9 (1976); Chem. Abs. 85, 186613K (1976).

46 H. B. Levy, G. Baer, S. Baron, C.E. Buckler, C.J. Gibbs, M.J. Iadarola, W.T. London and J. Rice: J. infect. Dis. 132, 434 (1975).

47 K. Champney, H. Levy, A. M. Lerner, D. Levine, L. Crane, E. J. Bailey and R. Cushing: Clin. Res. 24, A451 (1976).

48 M.A. Guggenheim and S. Baron: J. infect. Dis. 136, 50 (1977).

49 E. de Clercq, B. Zmudzka and D. Shugar: FEBS Lett. 24, 137 (1972).

50 K.H. Scheit, P. Faerber, K. Reuss and O. Saiko: German Pat. 2,130,544; Chem. Abs. 78, 84760a (1973).

51 J.T. Uchic, M. Uchic and A.D. Broom: Biochem. biophys. Res. Commun. 51, 494 (1973).

52 D. R. Black, F. Eckstein, J. B. Hobbs, H. Sternbach and T.C. Merigan: Virology 48, 537 (1972).

53 E. de Clercq and B. Janik: Biochem. biophys. Acta 324, 50 (1973).

54 E. de Clercq, V.G. Edy, P.F. Torrence, J.A. Waters and B. Witkop: Molec. Pharmac. 12, 1045 (1976).

55 Belg. Pat. to Beecham Group Limited, No.766,817 (1971).

56 E. de Clercq, M. Hattori and M. Ikehara: Nucl. Acids Res. 2, 121 (1975).

57 E. de Clercq, W.E. Stewart II, and P. de Somer: Infect. Immun. 6, 344 (1972).

58 D. R. Black, F. Eckstein, E. de Clercq and T.C. Merigan: Antimicrob. Ag. Chemother. 3, 198 (1973).

59 E. de Clercq, in: Selective Inhibitors of Viral Functions, p. 177. Ed. W.A. Carter. Chemical Rubber Co. Press, Cleveland, Ohio, 1973.

60 D. H. Metz: Adv. Drug Res. 10, 101 (1975).

61 W.J. Kleinschmidt, L.F. Ellis, E.B. Murphy and R.M. van Frank: Nature 220, 167 (1968).

62 G.T. Banks, K.W. Buck, E. B. Chain, F. Himmelweit, J.E. Marks, J.M. Tyler, M. Hollings, F. M. Last and O. M. Stone: Nature 218, 542 (1968).

63 K.W. Buck, E. B. Chain and F. Himmelweit: J. gen. Virol. 12, 131 (1971).

64 G.T. Banks, K.W. Buck, E. B. Chain, J.E. Darbyshire, F. Himmelweit, G. Ratti, T.J. Sharpe and D.N. Planterose: Nature 227, 505 (1970).

65 Beecham Group Limited, Brit. Pat. 1,230,011 (1971).

66 Beecham Group Limited, Belg. Pat. 752,198 (1970).

67 L.E. Day and L.F. Ellis: US Pat. 3,719,754 (1971); Chem. Abs. 78, 157875X (1973).

68 A. Tsunoda, F. Suzuki, N. Sato, K. Miyazaki and N. Ishida: Prog. Antimicrob. Anticancer Chemother., Proc. 6th Int. Congr. Chemother. 2, 832 (1970).

69 G. Chihara, Y. Maeda, J. Hamuro, T. Sasaki and F. Fukuoka: Nature 222, 687 (1969).

70 R. Ushiyama, Y. Nakai and M. Ikegami: Virology 77, 880 (1977).

71 W. J. Kleinschmidt and L.F. Ellis: Dev. Ind. Microbiol. 16, 128 (1975).

72 W. Regelson: J. Am. med. Ass. 201, 27 (1967).

73 T.C. Merigan and W. Regelson: New Engl. J. Med. 277, 1283 (1967).

74 P. de Somer, E. de Clercq, A. Billiau, E. Schonne and M. Claesen: J. Virol. 2, 886 (1968).

75 P. Claes, A. Billiau, E. de Clercq, J. Desmyter, E. Schonne, H. Vanderhaege and P. de Somer: J. Virol. 5, 313 (1970).

76 R.S. McCord, M.K. Breinig and P.S. Morahan: Antimicrob. Ag. Chemother. 10, 28 (1976).

77 E. de Clercq and M. Luczak: Arch. Virol. 52, 151 (1976).

78 M.W. Harmon and B. Janis: Antimicrob. Ag. Chemother. 6, 507 (1974).

79 G. D. Mayer and B. A. Fink: Fed. Proc. 29, 635, Abstr. 2189 (1970). 
80 A.D. Sill, W.L. Albrecht, E. R. Andrews, R.W. Fleming, S. W. Horgan, E. M. Roberts and F. W. Sweet: J. Med. Chem. 16, 240 (1973).

81 E.R. Andrews, R.W. Fleming, J.M. Grisar, J.C. Kihm, D.L. Wenstrup and G.D. Mayer: J. Med. Chem. 17, 882 (1974).

82 W.L. Albrecht, R.W. Fleming, S.W. Horgan, J.C. Kihm and G.D. Mayer: J. Med. Chem. 17, 886 (1974).

83 J.M. Grisar, K.R. Hickley, R.W. Fleming and G.D. Mayer: J. Med. Chem. 17, 890 (1974).

84 A.D. Sill, E. R. Andrews, F. W. Sweet, J.W. Hoffman, P.L. Tiernan, J. M. Grisar, R.W. Fleming and G.D. Mayer: J. Med. Chem. 17, 965 (1974).

85 W.L. Albrecht, R.W. Fleming, S.W. Horgan, B.A. Deck, J.W. Hoffman and G.D. Mayer: J. Med. Chem. 17, 1150 (1974).

86 A.A. Carr, J.F. Grunwell, A.D. Sill, D.R. Mayer, F.W. Sweet, B.J. Scheve, J.M. Grisar, R.W. Fleming and G.D. Mayer: J. Med. Chem. 19, 1142 (1976).

87 W.L. Albrecht, R.W. Fleming, S. W. Horgan and G.D. Mayer: J. Med. Chem. 20, 364 (1977).

88 R.F. Krueger and G.D. Mayer: Science 169, 1213 (1970).

89 R.W. Kuehne, W.L. Pannier and E.L. Stephen: Antimicrob. Ag. Chemother. 11, 92 (1977).

90 A.R. Rhoads, W.L. West and H.P. Morris: Res. Commun. Chem. Path. Pharmac. 6, 741 (1973).

91 M. Green, A. Rankin, G.F. Gerard, D.P. Grandgen and M.R. Green: J. nat. Cancer Inst. 55, 433 (1975).

92 H.E. Kaufman, M. Centifanto, E.D. Ellison and D.C. Brown: Proc. Soc. exp. Biol. Med. 137, 357 (1971).

93 G. M. Schiff, C.C. Linnemann, T. Rotte, G. Mayer and S. Trimble: Clin. Res. 21, 882 (1973).

94 G.L. Wampler, M. Kuperminc and W. Regelson: Cancer Chemother. Rep. Part 1, 57, 209 (1973).

95 S. Levine, R. Sowinski and W. L. Albrecht: Toxic. appl. Pharmac. 40, 137 (1977).

96 S.E. Walker: Clin. Immun. Immunopath. 8, 204 (1977).

97 S. Levine and R. Sowinski: Proc. Soc. exp. Biol. Med. 151, 264 (1976).

98 P. Meindl, G. Bodo and H. Tuppy: Arzneimittel-Forsch. 26, 312 (1976).

99 G. J. Gauthier: US Pat. 3,838,131 (1974); Chem. Abs. 81, 152029B (1974).

100 G.J. Gauthier: US Pat. 3,932,643 (1976); Chem. Abs. 84, 135502V (1976).

101 H.W. Sause: German Pat. 2,348,534; Chem. Abs. 81, 77813X (1974).

102 K. Raj, A. Shoeb, R. S. Kapil and S.P. Popli: Indian J. Chem., sect. B 14B, 371 (1976).

103 P. Siminoff, A.M. Bernard, V.S. Hursky and K.E. Price: Antimicrob. Ag. Chemother. 3, 742 (1973).

104 E.R. Kern, J.R. Hamilton, J.C. Overall and L.A. Glasgow: Antimicrob. Ag. Chemother. 10, 691 (1976).

105 P. Siminoff and R.R. Crenshaw: Antimicrob. Ag. Chemother. 11, 571 (1977).

106 R. R. Crenshaw, G. M. Luke and P. Siminoff: J. Med. Chem. 19, 262 (1976).

107 C. Panusarn, E.D. Stanley, V. Dirda, M. Rubenis and G.G. Jackson: New Engl. J. Med. 291, 57 (1974).

108 B. G. Gatmaitan, E.D. Stanley and G. G. Jackson: J. infect. Dis. 127, 401 (1973).

109 R.G. Douglas, R.F. Betts, R.L. Simons, P.W. Hogan and F. K. Roth: Antimicrob. Ag. Chemother. 8, 684 (1975).

110 F.R. Nichol, S.D. Weed and G.E. Underwood: Antimicrob. Ag. Chemother. 9, 433 (1976).

111 D. A. Stringfellow: Antimicrob. Ag. Chemother. 11, 984 (1977).

112 US Pat. 4,003,929 and 4,034,040 (1977).

113 E. Lvovsky, H. B. Levy, D. G. Doherty and S. Baron: Infect. Immun. 15, 191 (1977).

114 C.E. Hoffmann, in: Selective Inhibitors of Viral Functions, p. 199. Chemical Rubber Co. Press, Cleveland, Ohio, 1973. 
115 P.E. Aldrich, E.C. Hermann, W.E. Mayer, M. Paulshock, W.W. Prichard, J. A. Snyder and J.C. Watts: J. Med. Chem. 14, 535 (1971).

116 J.M. O’Donoghue, C. G. Ray, D. W. Terry and H.N. Beaty: Am. J. Epidemiol. 97, 276 (1973).

117 A.W. Galbraith and G.I. Watson, in: Chemoprophylaxis and Virus Infections of the Respiratory Tract, vol. II, p. 57. Chemical Rubber Co. Press, Cleveland, Ohio, 1977.

118 G.I. Danilenko, V.I. Votyakov, O.T. Andreeva, M. M. Timofeeva, M.N. Shashikhina, L.V. Denisova, E.I. Boreko, I.V. Bruskova, E.I. Dikolenko and N.A. Smirnova: Khim.-Farm. Zh. 10, 49 (1976); Chem. Abs. 85, 108360M (1976).

119 G.I. Danilenko, V.I. Votyakov, O.T. Andreeva, E.I. Boreko, L.V. Denisova, M.N. Shashikhina, M.M. Timofeeva, E.I. Dikolenko and T.N. Utochka: Khim.-Farm. Zh. 10, 37 (1976); Chem. Abs. 85, 192264P (1976).

120 G.I. Danilenko, V.I. Votyakov, O.T. Andreeva, M.N. Shashikhina, M. M. Timofeeva, L.V. Denisova, E.I. Boreko and M.I. Novikova: Khim.-Farm. Zh. 10, 60 (1976); Chem. Abs. 86, 120855E (1977).

121 G.I. Danilenko, V.I. Votyakov, O.T. Andreeva, V.A. Rusyaev, E.I. Boreko and I.V. Bruskova: Khim.-Farm. Zh. 11, 71 (1977); Chem. Abs. 87, 67923T (1977).

122 M. Indulena, I. Kanele, D. Dzeguze, G. M. Ryazantseva, J. Polis and B. Vilne: Khim. Khim. Grippa Mater Vses. Simp. 1st, p. 38 (1971); Chem. Abs. 82, 68321 (1975).

123 M. Indulena, V. Kalnina, G.M. Ryazantseva and V.I. Bubovich: Latv. PSR Zinat. Akad. Vestis, Issue 3, 17 (1977.); Chem. Abs. 86, 182856Q (1977).

124 D.M. Zlydnikov, G.I. Aleksandrova, Yu.A. Romanov, V.I. Rumovskii and B.I. Vasil'ev: Ingibitory Virus. Aktiv., p. 93 (1972); Chem. Abs. 77, 147534A (1972).

125 A. Tsunoda, H.F. Maassab, K.W. Cochran and W.C. Eveland: Antimicrob. Ag. Chemother., p.553 (1965).

126 A.T. Dawkins, L.R. Gallager, Y. Togo, R.B. Hornick and B. A. Harris: J. Am. med. Ass. 203, 93 (1968).

127 S. Rabinovich, J. T. Baldini and R. Bannister: Am. J. med. Sci. 257, 328 (1969).

128 W.L. Wingfield, D. Pollack and R. R. Grunert: New Engl. J. Med. 281, 579 (1969).

129 V.P. Mazhinskaya and M.R. Antipova: Khim. Khim. Grippa Mater Vses. Simp. 1st, p. 92 (1971); Chem. Abs. 82, 106552 (1975).

130 British Broadcasting Company interview with Russian Science Correspondent, 12 April 1977.

131 G. A. Galegov, A.A. Yatsyna, G.L. Linitskaya and N.L. Pushkars: Biokhimiya 41, 2237 (1976).

132 V.V. Dikii, A.S. Petkevich, N.A. Leont'eva and G.A. Galegov: Vop. med. Khim. 22, 844 (1976); Chem. Abs. 86, 83545F (1977).

133 V.I. Il'enko, V.G. Platonov and I.K. Khomenkova: Vop. Virusol. Issue 2, 223 (1977); Chem. Abs. 87, 78401X (1977).

134 G.A. Galegov, N.L. Pushkarskaya, N.P. Obrosova-Serova and V.M. Zhdanov: Experientia 33, 905 (1977).

135 A. Denys, S. Szram, W. Tkaczewski, H. Niedzielska, J. Bochenska, M. Kulawczyk, L. Szymanski and E. Zujewski: Acta microbiol. Pol. (A) 5, 217 (1973).

136 N.L. Pushkarskaya, V.K. Blinova, R.Ya. Podchernyaeva, N.P. Obrosova-Serova, G.A. Galegov, D. K. Lvov and V.M. Zhdanov: Vop. Virusol., p. 369 (1977).

137 H.W. Geluk and J.L.M.A. Schlatmann: Tetrahedron 24, 5361 (1968).

138 Phillips N.V., Neth. Pat. 66,05485 (1966); Chem. Abs. 68, 33177V (1968).

139 K. Lundahl, J. Schut, J.L.M.A. Schlatmann, G.B. Paerels and A. Peters: J. Med. Chem. 15, 129 (1972).

140 R. van Hes, A. Smit, T. Kralt and A. Peters: J. Med. Chem. 15, 132 (1972).

141 A.S. Beare, T.S. Hall and D. A.J. Tyrrell: Lancet 1972, part 1, 1039.

142 A. Mathur, A.S. Beare and S.E. Reed: Antimicrob. Ag. Chemother. 4, 421 (1973).

143 T. Sasaski: Japan. Pat., Kokai 76,118,762 (1975); Chem. Abs. 86, 189,929Z (1977).

144 K. Aigami: US Pat. 3,962,328 (1974); Chem. Abs. 86, 43297V (1977).

145 K. Aigami: Japan. Pat., Kokai 75,148,343 (1974); Chem. Abs. 84, 164287J (1976). 
146 K. Aigami: German Pat. 2,449,840 (1973); Chem. Abs. 83, 96571Z (1975).

147 K. Aigami: Japan. Pat., Kokai 75,148,366 (1974); Chem. Abs. 85, 94396P (1976).

148 Y. Inamoto, K. Aigami and K. Hattori: Japan. Pat., Kokai 75,116,613 (1974); Chem. Abs. 83, 188518R (1975).

149 H. Nesvadba and H. Reinshagen: Swiss Pat. 578,513 (1973); Chem. Abs. 85, 176965N (1976).

150 H. Nesvadba and H. Reinshagen: Swiss Pat. 576,428 (1973); Chem. Abs. 85, 77760K (1976).

151 H. Nesvadba and H. Reinshagen: Swiss Pat. 578,518 (1973); Chem. Abs. 85, 176966P (1976).

152 Y. Inamoto, K. Aigami and K. Hattori: Japan. Pat., Kokai 75,111,216 (1974); Chem. Abs. 83, 188515 (1975).

153 Y. Inamoto, K. Aigami, K. Hattori and T. Kakuno: Japan. Pat., Kokai 75,111,218 (1974); Chem. Abs. 83, 188517Q (1975).

154 G. May and D. Peteri: Arzneimittel-Forsch. 23, 718 (1973).

155 A. Winkler: Med. Welt. 24, 1024 (1973).

156 D. Fanta and P. Mischer: Contact Dermat. 2, 282 (1976).

157 W. B. Flagg, F.J. Stanfield, R.F. Haff, R.C. Stewart, R.J. Stedman, J.A. Gold and R. J. Ferlauto: Antimicrob. Ag. Chemother., p. 194 (1968).

158 Y. Togo, A.R. Schwartz, S. Tominaga and R. B. Hornick: J. Am. med. Ass. 220, 837 (1972).

159 M. Tisdale and D.J. Bauer: Ann. N.Y. Acad. Sci. 284, 254 (1977).

160 K. Aigami, Y. Inamoto, N. Takaishi and Y. Fujikura: J. Med. Chem. 19, 536 (1976).

161 R.A. Bucknall, unpublished results.

162 K. Schaffner, A. Storni and A. Meisels: German Pat. 2,411,640 (1973); Chem. Abs. 82, 124910J (1975).

163 French Medicament Pat. 8401; Chem. Abs. 81, 120820M (1974).

164 P.J. May: Brit. Pat. 1,468,349 (1977).

165 K. Schaffner, A. Meisels, J.C. Roger and C. Weis: German Pat. 2,321,057 (1972); Chem. Abs. 80, 70711H (1974).

166 R.W. Tankersley: US Pat. 4,005,224; Chem. Abs. 86, 161301Q (1977).

167 H.E. Alburn and N.H. Grant: US Publ. Pat. Applic. B, 386,257 (1971); Chem. Abs. 84, 135181Q (1976).

168 G.H. Beresin and W.E. Meier: German Pat. 2,334,984 (1972); Chem. Abs. 80, $120763 Z$ (1974).

169 I. Tamm, H.J. Eggers, R. Bablanian, A.F. Wagner and K. Folkers: Nature 223, 785 (1969).

170 L.A. Caliguiri and I. Tamm, in: Selective Inhibitors of Viral Functions, p.277. Ed. W.A. Carter. Chemical Rubber Co. Press, Cleveland, Ohio, 1973.

171 F. Gualtieri, G. Brody, A.H. Fieldsteel and W.A. Skinner: J. Med. Chem. 15, 420 (1972).

172 H.J. Eggers: J. exp. Med. 143, 1367 (1976).

173 S.B. Kadin, H.J. Eggers and I. Tamm: Nature 201, 639 (1964).

174 J.B. Schleicher, F. Aquino, A. Rueter, W.R. Roderick and R.N. Appell: Appl. Microbiol. 23, 113 (1972).

175 W.R. Roderick, C.W. Nordeen, Jr., A.M. von Esch and R.N. Appell: J. Med. Chem. 15, 655 (1972).

176 N.L. Shipkowitz, R.R. Bower, J.B. Schleicher, F. Aquino, R.N. Appell and W.R. Roderick: Appl. Microbiol. 23, 117 (1972).

177 W. McCormick and H.T. Shigeura: Fed. Proc. 30, Abstr. 1178 (1971).

178 N.R. Trenner, J.R. Carlin, B.H. Arison and W.J.A. van den Heuvel: J. Pharm. Sci. 63, 1312 (1974).

179 S. Akihama, K. Takahashi and N. Miyajima: J. Pharm. Soc., Japan 94, 247 (1974).

180 M.E. Leon, C.E. Coto and M.C. Weissenbacher: Medicinia, Buenos Aires 36, 406 (1976); Chem. Abs. 86, 100843W (1977). 
181 V.S. Misra and K.M. Varshneya: Indian J. Pharm. 39, 35 (1977).

182 C.J. Paget, J.W. Chamberlin and J.H. Wikel: German Pat. 2,638,551 (1975); Chem. Abs. 87, 53298 (1977).

183 J.H. Wikel and C.J. Paget: US Pat. 4,008,243 (1975); Chem. Abs. 86, 189940 (1977).

184 W. Levinson, in: Selective Inhibitors of Viral Functions, p.213. Ed. W.A. Carter. Chemical Rubber Co. Press, Cleveland, Ohio, 1973.

185 V.S. Misra and M. Varshneya: Indian J. Pharm. 37, 60 (1975).

186 A. Andreani, D. Bonazzi, V. Cavrini, R. Gatti, G. Giovanni, L. Franchi and A. Nanetti: Farmaco, Ed. sci. 32, 703 (1977).

187 E. Katz, E. Margalith and B. Winer: J. Antimicrob. Chemother. 2, 255 (1976).

188 R. Franke, D. Labes, M. Tonew, W. Zschiesche and L. Heinisch: Acta biol. med. Germ. 34, 491 (1975).

189 M. Tonew, E. Tonew and L. Heinisch: Acta Virol. 18, 17 (1974).

190 L. Heinisch and M. Tonew: Pharmazie 31, 840 (1976).

191 W. Levinson, H. Oppermann and J. Jackson: J. gen. Virol. 37, 183 (1977).

192 J. A. Levy, S. B. Levy and W. Levinson: Virology 74, 426 (1976).

193 J.C. Logan, M.P. Fox, J.H. Morgan, A.M. Makohon and C.J. Pfau: J. gen. Virol. 28, 271 (1975).

194 M.P. Fox, L.H. Bopp and C. J. Pfau: Ann. N.Y. Acad. Sci. 284, 533 (1977).

195 W. Levinson, W. Rohde, P. Mikelens, J. Jackson, A. Antony and T. Ramakrishnan: Ann. N.Y. Acad. Sci. 284, 525 (1977).

196 J.S. Oxford and D.D. Perrin: Ann. N.Y. Acad. Sci. 284, 613 (1977).

197 D.D. Perrin, in: Chemoprophylaxis and Viruses of the Respiratory Tract, vol.II, p. 201. Ed. J.S. Oxford. Chemical Rubber Co. Press, Cleveland, Ohio, 1977.

198 C.P. Hegarty and H.C. Pietryk: US Pat. 3,980,774 and 4,032,659; Chem. Abs. 85, 154151 (1976).

199 J. Boyle, W. Raupp, F. Stanfield, R.F. Haff, E. Dick, D. D'Alessio and C. Dick: Ann. N.Y. Acad. Sci. 173, 477 (1970).

200 J.M.Z. Gladych, R. Hornby, J.H. Hunt, D. Jack, J. J. Boyle, R. J. Ferlauto, R.F. Haff, C. G. Kormendy, F. J. Stanfield and R.C. Stewart: J. Med. Chem. 15, 277 (1972).

201 C.A. Pinto, H.P. Bahnsen, L.J. Ravin, R.F. Haff and J. Pagano: Proc. Soc. exp. Biol. Med. 141, 461 (1972).

202 C. J. Dicuollo, J.E. Zarembo and J.F. Pagano: Xenobiotica 3, 171 (1973).

203 J.A. Gold: Ann. N.Y. Acad. Sci. 173, 808 (1970).

204 Y. Togo, A. R. Schwartz and R. B. Hornick: Chemotherapy 18, 17 (1973).

205 S.E. Reed, J.W. Craig and D. A.J. Tyrrell: J. infect. Dis. 133, suppl. A128 (1976).

206 M.R. Bell and A.W. Zalay: J. Het. Chem. 12, 1001 (1975).

207 V. Tuli, H. S. Moyed, D. Stevenson and I. Gordon: Antimicrob. Ag. Chemother. 5, 479 (1974).

208 V. Tuli: Antimicrob. Ag. Chemother. 5, 485 (1974).

209 S. L. Abreu and J. Lucas-Lenard: Antimicrob. Ag. Chemother. 11, 521 (1977).

210 K. Shinkai and T. Nishimura: J. gen. Virol. 16, 227 (1972).

211 B. R. Murphy and L.A. Glasgow: Ann. N.Y. Acad. Sci. 173, 255 (1970).

212 Y. Togo, A. R. Schwartz and R. B. Hornick: Antimicrob. Ag. Chemother. 4, 612 (1973).

213 K. Gerzon, D.C. Delong, L.A. Baker, V. Button, J.D. Nelson and C.W. Ryan: 163rd A.C.S. Meeting, Boston, Abstracts of Papers, p. MEDI 18 (1972); Pharmascope 12, 115 (1972).

214 Canada Packers Ltd., Brit. Pat. 1,439,318 (1976).

215 D. Ajdukovic and K.R. Bharucha: 9th Int. Congr. Chemother., London (1975), Abstract M-335.

216 P. A.J. Janssen: Prog. Drug Res. 20, 347 (1976).

217 R. J. O'Reilly, A. Chibbaro, R. Wilmot and C. Lopez: Ann. N.Y. Acad. Sci. 284, 161 (1977).

218 J.W. Hadden, C. Lopez, R. J. O’Reilly and E. M. Hadden: Ann. N.Y. Acad. Sci. 284, 139 (1977). 
219 J.C. Pelling and C. Shipman, Jr.: Biochem. Pharmac. 25, 2377 (1976).

220 Brit. Pat. 1,357,733 (Glaxo Ltd.) (1974).

221 H. J. Eggers: Virology 78, 241 (1977).

222 M.A. Verini, A. Fioretti, A. M. Casazza, A. Sanfilippo, G. Palamide and M. Ghione: Chemotherapy 21, 221 (1975).

223 K.W. Ehler, R.K. Robins and R. B. Meyer, Jr.: J. Med. Chem. 20, 317 (1977).

224 J.T. Witkowski, R. K. Robins, R.W. Sidwell and L. N. Simon: J. Med. Chem. 14, 1150 (1972).

225 R.W. Sidwell, J.H. Huffman, G.P. Khare, J.T. Witkowski and R.K. Robins: Science 177, 705 (1972).

226 D. G. Streeter, J.T. Witkowski, G.P. Khare, R.W. Sidwell, R.J. Bauer, R. K. Robins and L.N. Simon: Proc. nat. Acad. Sci. USA 70, 1174 (1973).

227 J.K. Lowe, L. Brox and F. J. Henderson: Cancer Res. 37, 736 (1977).

228 D. G. Streeter, J.P. Miller, R. K. Robins and L.N. Simon: Ann. N.Y. Acad. Sci. 284, 201 (1977).

229 Many authors: Ann. N.Y. Acad. Sci. 284, 201-284 (1977).

230 B. Eriksson, E. Helgstrand, N.G. Johansson, A. Larsson, A. Misiorny, J.O. Noren, L. Philipson, K. Stenberg, G. Stening, S. Stridh and B. Öberg: Antimicrob. Ag. Chemother. 11, 946 (1977).

231 F.E. Durr, H.F. Lindh and M. Forbes: Antimicrob. Ag. Chemother. 7, 582 (1975).

232 Y. Togo and A. McCracken: J. infect. Dis. 133, suppl. A109 (1976).

233 C.R. Magnussen, R.G. Douglas, R.F. Betts, F.K. Roth and R.M.P. Meaghe: Antimicrob. Ag. Chemother. 12, 498 (1977).

234 F. Salido-Rengell, H. Nasser-Quinones and B. Briseno-Garcia: Ann. N.Y. Acad. Sci. 284, 272 (1977).

235 R.A. Bucknall and D.A. Rutty, in: Chemoprophylaxis and Virus Infections of the Respiratory Tract, vol. II, p. 143. Chemical Rubber Co. Press, Cleveland, Ohio 1977.

236 L. Kilham and V.H. Ferm: Science 195, 413 (1977).

237 L. N. Simon: Ann. N.Y. Acad. Sci. 284, 290 (1977).

238 J.T. Witkowski, R.K. Robins, G.P. Khare and .R.W. Sidwell: J. Med. Chem. 16, 935 (1973).

239 P.C. Srivastava, D. G. Streeter, T.R. Matthews, L. B. Allen, R.W. Sidwell and R. K. Robins: J. Med. Chem. 19, 1020 (1976).

240 M.S. Poonian, E.F. Nowoswiat, J.F. Blount and M.J. Kramer: J. Med. Chem. 19, 1017 (1976).

241 P.C. Srivastava, M.V. Pickering, L.B. Allen, D. G. Streeter, M.T. Campbell, J.T. Witkowski, R.W. Sidwell and R. K. Robins: J. Med. Chem. 20, 256 (1977).

242 M.S. Poonian and E.F. Nowoswiat: J. org. Chem. 42, 1109 (1977).

243 M. V. Pickering, J.T. Witowski and R. K. Robins: J. Med. Chem. 19, 841 (1976).

244 Japan. Pat. J5-2068-182 (1977).

245 L.T. Ch'ien, F.M. Schabel, Jr., and C.A. Alford, in: Selective Inhibitors of Viral Functions, p. 227. Chemical Rubber Co. Press, Cleveland, Ohio 1973.

246 Many authors: Ann. N.Y. Acad. Sci. 255 (1975).

247 Many authors: Ann. N.Y. Acad. Sci. 284, 3-103 (1977).

248 L.T. Ch'ien, N.J. Cannon, J. Charamella, W.E. Dismukes, R.J. Whitley, R.A. Buchanan and C. A. Alford: J. infect. Dis. 128, 658 (1973).

249 L.T. Ch'ien, R.J. Whitley, A.J. Nahmias, E. B. Lewin, C. C. Linneman, L.D. Frenkel, J.A. Bellanti and R. Buchanan: Pediatrics 55, 678 (1975).

250 G.N. Chin: J. Kentucky Med. Ass. 75, 322 (1977).

251 R.J. Whitley, L.T. Ch'ien, R. Dolin, G.J. Galasso and C.A. Alford: New Engl. J. Med. 294, 1193 (1976).

252 M.T. Johnson, J.P. Luby, R.A. Buchanan and D. Mikulec: J. infect. Dis. 131, 225 (1975).

253 M.D. Aronson, C.F. Phillips, D.W. Gump, R. Albertini and A. Phillips: J. Am. med. Ass. 235, 1339 (1976). 
254 G. O. Waring, P.R. Laibson, J.E. Satz and N. H. Joseph: Am. J. Ophthal. 82, 781 (1976).

255 S. M. Kurtz, J.E. Fitzgerald and J.L. Schardein: Ann. N.Y. Acad. Sci. 284, 6 (1977).

256 Y.J. Bryson and J.D. Connor: Antimicrob. Ag. Chemother. 9, 540 (1976).

257 Y.J. Bryson and L.H. Kronenberg: Antimicrob. Ag. Chemother. 11, 299 (1977).

258 R.W. Sidwell, L.B. Allen and many authors: Antimicrob. Ag. Chemother. 8, 463, 468, 474 (1975).

259 H.W. Dion, P. W. K. Woo and A. Ryder: Ann. N.Y. Acad. Sci. 284, 21 (1977).

260 B.J. Sloan, J. K. Kielty and F. A. Miller: Ann. N.Y. Acad. Sci. 284, 60 (1977).

261 W. Plunkett and S. S. Cohen: Ann. N.Y. Acad. Sci. 284, 91 (1977).

262 E. de Clercq, J. Descamps, E. Krajeswka and D. Shugar: Biochem. Pharmac. 26, 794 (1977).

263 C. Lopez and A. Giner-Sorolla: Ann. N.Y. Acad. Sci. 284, 351 (1977).

264 G. B. Elion, J.L. Rideout, P. de Miranda, P. Collins and D. J. Bauer: Ann. N.Y. Acad. Sci. 255,468 (1975).

265 J.A. Montgomery, A.T. Shortnacy, G. Arnett and W.M. Shannon: J. Med. Chem. 20, 401 (1977).

266 R. Vince and S. Daluge: J. Med. Chem. 20, 612 (1977).

267 T. A. Khwaja and R.K. Robins: German Pat. 2,254,645; Chem. Abs. 81, 63931 (1974).

268 R. L. Tolman: US Pat. 3,826,803; Chem. Abs. 84, 136010 (1976).

269 T.H. Haskell: Ann. N.Y. Acad. Sci. 284, 81 (1977).

270 A.W. Karchmer and M.S. Hirsch: New Engl. J. Med. 289, ? 12 (1973).

271 C. B. Lauter, E. J. Bailey and A. M. Lerner: Antimicrob. Ag. Chemother. 6, 598 (1974).

272 M.W. Harmon and J. Burton: J. infect. Dis. 133, 7 (1976).

273 J.F. Griffith, J.F. Fitzwilliam, S. Casagrande and S. R. Butler: J. infect. Dis. 132, 506 (1975).

274 E. Lefkowitz, M. Worthington, M. A. Conliffe and S. Baron: Proc. Soc. exp. Biol. Med. 152, 337 (1976).

275 J.C. Drach and C. Shipman, Jr.: Ann. N.Y. Acad. Sci. 284, 396 (1977).

276 D. K. Kelsey, E. R. Kern, J.C. Overall and L.A. Glasgow: Antimicrob. Ag. Chemother. 9, 458 (1976).

277 E. de Clercq, E. Darzynkiewicz and D. Shugar: Biochem. Pharmac. 24, 523 (1975).

278 K. Sato, A. Nomura and J. G. Moffatt: Antimicrob. Ag. Chemother. 11, 191 (1977).

279 S. Nishiyama, K. Sato, T. Yamanaka and J.G. Moffatt: Antimicrob. Ag. Chemother. 11, 198 (1977).

280 D.T. Gish, G.D. Gray and W.J. Wechter: US Pat. 3,975,367; Chem. Abs. 85, 177995 (1976).

281 T.L. Loo, D.H.W. Ho, G.P. Bodey and E.J. Freireich: Ann. N.Y. Acad. Sci. 255, 252 (1975).

282 E.K. Hamamura, M. Prystasz, J.P.H. Verheyden, J.G. Moffatt, K. Yamaguchi, N. Uchida, K. Sato, A. Nomura, O. Shiratori, S. Takase and K. Katagiri: J. Med. Chem. 19, 654, 663 (1976).

283 M. Morozumi, Y. Noda, T. Fujishima, M. Suzuki and H. Yoshino: Japan. Pat., Kokai 75,142,599; Chem. Abs. 84, 136011 (1976).

284 R.A. Long, G.L. Szekeres, T.A. Khwaja, R.W. Sidwell, L.N. Simon and R. K. Robins: J. Med. Chem. 15, 1215 (1972).

285 R.W. Sidwell, L.N. Simon, J.H. Huffman, L.B. Allen, R. A. Long and R.K. Robins: Nature, New Biol. 242, 204 (1973).

286 G. A. Gentry and J.F. Aswell: Fed. Proc. 34, 807 (1975).

287 J.F. Ashwell, G.P. Allen, A.T. Jamieson, D.E. Campbell and G. A. Gentry: Antimicrob. Ag. Chemother. 12, 243 (1977).

288 J.F. Aswell and G. A. Gentry: Ann. N.Y. Acad. Sci. 284, 342 (1977).

289 M.N. Artemjeva: Khim.-Farm. Zh. 8, 26 (1974).

290 G.R. Revankar, J.H. Huffman, R.W. Sidwell, R.L. Tolman, R.K. Robins and L.B. Allen: J. Med. Chem. 19, 1026 (1976).

291 H.E. Kaufman: Proc. Soc. exp. Biol. Med. 109, 251 (1962). 
292 J. Sugar and H.E. Kaufman, in: Selective Inhibitors of Viral Functions, p.295. Chemical Rubber Co. Press, Cleveland, Ohio 1973.

293 J. C. Leonard and L. G. Lajtha: Postgrad. Med. J. 49, 410 (1973).

294 P. Collins and D. J. Bauer: Ann. N.Y. Acad. Sci. 284, 49 (1977).

295 S. R. Harris and M. R. Boyd: J. Antimicrob. 3, 91 (1977).

296 G. Plummer and A. P. Ingerson: Antimicrob. Ag. Chemother. 5, 672 (1974).

297 C.T. Cho, C. Liu, D. W. Voth and K. K. Feng: J. infect. Dis. 128, 718 (1973).

298 S.E. Stewart, G. Kasnic, C. Draycott, W. Feller, A. Golden, E. Mitchell and T. Ben: J. nat. Cancer Inst. 48, 273 (1972).

299 N.R. Paul, S. Iwakata, A.J. Rhodes and N. A. Labzoffsky: Arch. ges. Virusforsch. 44, 144 (1974).

300 J. Varani and J.J. Kelleher: Antimicrob. Ag. Chemother. 8, 18 (1975).

301 W.H. Prusoff, D.C. Ward, T.S. Lin, M.S. Chen, G.T. Shaiu, C. Chai, E. Lentz, R. Capizzi, J. Idriss and N.H. Ruddle: Ann. N.Y. Acad. Sci. 284, 335 (1977).

302 P.H. Fischer, M.S. Chen and W.H. Prusoff: Pharmacologist 19, 209 (1977).

303 T.S. Lin, J.P. Neenan, Y.C. Cheng and W.H. Prusoff: J. Med. Chem. 19, 495 (1976).

304 T.S. Lin, C. Chai and W.H. Prusoff: J. Med. Chem. 19, 915 (1976).

305 P.C. Wellings, P.N. Awdry, F.H. Bors, B.R. Jones, D.C. Brown and H.E. Kaufman: Am. J. Ophthal. 73, 932 (1972).

306 J. Am. med. Ass. 237, 481 (1977).

307 D. W. Clough and J.R. Parkhurst: Antimicrob. Ag. Chemother. 11, 307 (1977).

308 C. Heidelberger: Ann. N.Y. Acad. Sci. 255, 317 (1975).

309 G.A. Galegov, T.A. Bektemirov, T.V. Veselovskaya and S. V. Lavrov: Vop. Virusol., p. 47 (1975).

310 R.M. Bikbulatov, P. Langen and G.A. Galegov: Vop. Virusol., p. 625 (1975).

311 Y.C. Cheng, J.P. Neenan, B. Goz, D. C. Ward and W.H. Prusoff: Ann. N.Y. Acad. Sci. 255, 332 (1975).

312 S. Greer, I. Schildkraut, T. Zimmerman and H. Kaufman: Ann. N.Y. Acad. Sci. 255, 359 (1975).

313 M.A. Jerkofsky, M.J. Dobersen and S. Greer: Ann. N.Y. Acad. Sci. 284, 389 (1977).

314 M.J. Dobersen, M. Jerkofsky and S. Greer: J. Virol. 20, 478 (1976).

315 I. Inoue, T. Adachi and K. Kondo: Japan. Pat., Kokai 76,36467 (1974); Chem. Abs., 85, 63304 (1976).

316 T. Marunaka, M. Yasumoto, S. Hashimoto, K. Harima and T. Suzue: Japan. Pat., Kokai 75,105673-4 (1974); Chem. Abs. 84, 59542-3 (1976).

317 M. Yasumoto, T. Marunaka, S. Hashimoto, K. Harima and T. Suzue: Japan. Pat., Kokai 75,50384 (1973); Chem. Abs. 83, 193366 (1975).

318 E. de Clercq, P.F. Torrence, J.A. Waters and B. Witkop: Biochem. Pharmac. 24, 2171 (1975).

319 J.B. Meldrum, V.S. Gupta and J.R. Saunders: Antimicrob. Ag. Chemother. 6, 393 (1974).

320 E. de Clercq and D. Shugar: Biochem. Pharmac. 24, 1073 (1975).

321 B.A. Domin, Y.C. Cheng, R.A. Sharma and M. Bobek: Pharmacologist 17, 229 (1975).

322 V.S. Gupta, G. L. Bubbar, J. B. Meldrum and J.R. Saunders: J. Med. Chem. 18, 973 (1975).

323 Y.C. Cheng, B.A. Domin, R.A. Sharma and M. Bobek: Antimicrob. Ag. Chemother. 10, 119 (1976).

324 R.A. Sharma: Am. Chem. Soc. Abstr. 172nd Meeting, p. MEDI 70 (1976).

325 P.F. Torrence, B. Bhooshan, J. Descamps and E. de Clercq: J. Med. Chem. 20, 974 (1977).

326 Report in: Am. Drugg., p. 49 (1970).

327 R.L. Muldoon, L. Mezny and G.G. Jackson: Antimicrob. Ag. Chemother. 2, 224 (1972).

328 J. Pediat. (Rio de Janeiro) 37, 261 (1972); Excerpta med. 3.7; Virology Abstr., p. 2385 (1973). 
329 P. Gordon and E. R. Brown: Can. J. Microbiol. 18, 1463 (1972).

330 P. Gordon, B. Ronsen and E. R. Brown: Antimicrob. Ag. Chemother. 5, 153 (1974).

331 T. Ginsberg and A. J. Glasky: Ann. N.Y. Acad. Sci. 284, 128 (1977).

332 G. Renoux, M. Renoux and J.M. Guillaume: Ann. Immun. C128, 968 (1977).

333 R.H. Waldman and R. Ganguly: Ann. N.Y. Acad. Sci. $284 \ddot{u} 153$ (1977).

334 L.A. Glasgow and G. J. Galasso: J. infect. Dis. 126, 162 (1972).

335 H.J. Eggers, A. Neufahrt and H. Rolly: Dt. med. Wschr. 97, 1156 (1972).

336 A.J. Soto, T.S. Hall, S.E. Reed and D.J. Tyrrell: Antimicrob. Ag. Chemother. 3, 332 (1973).

337 D. M. Pachuta, Y. Togo, R.B. Hornick, A. R. Schwartz and S. Tominaga: Antimicrob. Ag. Chemother. 5, 403 (1974).

338 S. Longley, L.R. Dunning and R.H. Waldman: Antimicrob. Ag. Chemother. 3, 506 (1973).

339 L. J. Bradshaw and H. L. Sumner: Ann. N.Y. Acad. Sci. 284, 190 (1977).

340 S. Toyoshima, Y. Seto, H. Fujita, N. Toneki, J. Abe, T. Watanabe, K. Fijimoto and S. Kohari: Japan. Pat., Kokai 73,21934 and 73,21935; Chem. Abs. 79, 104966 and 146249 (1973).

341 H. Fujita, Y. Seto and S. Toyoshima: Antimicrob. Ag. Chemother. 7, 426 (1975).

342 US Pat. 4,025,555 (1977).

343 L.A. Caliguiri and I. Tamm, in: Selective Inhibitors of Viral Functions, p.257. Ed. W.A. Carter. Chemical Rubber Co. Press, Cleveland, Ohio 1973.

344 P. La Colla, A. M. Cioglia, O. Zuffardi, C. de Giuli and B. Loddo: G. ital. Chemioter. 17, 299 (1970); Chem. Abs. 77, 57036 (1972).

345 A.S. Koch, T. Eremenko, A. Benedetto and P. Volpe: Intervirology 4, 221 (1975).

346 H. Nick and R. Ahl: Arch. Virol. 52, 71 (1976).

347 US Pat. 4,027,039 (1977).

348 I. Kajiwara, I. Yo and H. Ito: Japan. Pat., Kokai 75,04038 (1972); Chem. Abs. 84, 4701 (1976).

349 M. Bracha, D. Sagher, A. Brown and M. J. Schlesinger: Virology 77, 45 (1977).

350 R.A. Bucknall, D. L. Swallow, H. Moores and J. Harrad: Nature 246, 144 (1973).

351 D. L. Swallow, R.A. Bucknall, W.E. Stanier, A. Hutchinson and H. Gaskin: Ann. N.Y. Acad. Sci. 284, 304 (1977).

352 D. L. Swallow: Brit. Pat. 1,492,678 (1977); Chem. Abs. 87, 67913 (1977).

353 American Cyanamid Co., Belg. Pat. 850,148 (1977).

354 Y. Togo, F.E. Durr and D. A. Laurenzana: Med. Microbiol. Immun. 163, 37 (1977).

355 A. Denys, T. Machlanski, J. Bialek: Zentbl. Bakt. Parasit. Infektionskr. 164, 85 (1977).

356 A. Bailey and M. Longson: J. clin. Path. 25, 76 (1972).

357 M.Ya. Kraft, V.V. Katyshkina, G.N. Pershin and N.S. Bogdanova: Farmak. Toks. 29, 597 (1966).

358 A.N. Grinev: Khimioprofil. Khimioter. Grippa, Mater. Vses., p. 50 (1972); Chem. Abs. 82,68080 (1975).

359 G.N. Pershin, N.S. Bogdanova, I.S. Nicolaeva, A.N. Grinev, G. Ya. Uretskaya and N.V. Arkhangel'skaya: Farmak. Toks. 38, 69 (1975); Chem. Abs. 82, 118979 (1975).

360 Yu.A. Romanov, V.I. Rumovskii, V.P. Mazhinskaya and L.G. Rudenko: Mol. Biol. Virusov, Khimioter. Khimioprofil., p. 219 (1974); Chem. Abs. 85, 41071 (1976).

361 Review of Russian Antiviral Chemotherapy. J. infect. Dis. 130, 692 (1974).

362 M.P. Zykov, D.M. Zlydnikov, Yu.A. Romanov, E. G. Shvetsova, A. M. Malysheva, G. G. Klimanova, V.I. Rumovskii and L. G. Rudenko: Vop. Virusol., p. 58 (1975).

363 V.F. Krylov, A.A. Alekseeva, T.Ya. Lyarskaya and M.L. Berlyand: Mol. Biol. Virus Khim. Khim. Virus Infect. Mater. Ob'edin Sess. Otd. Gig. Mikrobiol. Epidem. Akad. Med. Nauk. SSSR Beloruss. Inst. Epid. Mikro., p. 144 (1974); Chem. Abs. 85, 56945 (1976).

364 V.I. Il'enko, V.G. Platonov and I.K. Khomenkova: Vop. Virusol., p. 223 (1977); Chem. Abs. 87, 78401 (1977).

365 D. M. Zlydnikov, Yu. A. Romanov and V.I. Rumovskii: Farmak. Toks. 33, 590 (1970). 
366 R.A. Bucknall and D. L. Swallow, unpublished results.

367 A. N. Grinev, M.Ya. Kraft, G. M. Borodina, E.N. Sytina, G. N. Pershin, N. S. Bogdanova, G. V. Yaroslavtseva and I.S. Nikolaeva: Khim.-Farm. Zh. 4, 61 (1970).

368 I. Sujak and B. Rada: Acta Virol. 21, 260 (1977).

369 A.L. Mikerina, N.S. Bogdanova, G. N. Pershin, V.I. Shvedov and A.N. Sytina: Brit. Pat. 1,430,726 (1974); Chem. Abs. 85, 68281 (1976).

370 N.S. Bogdanova, G.N. Pershin and I.S. Nikolaeva: Prog. Chemother. (Antibact. Antivir.) 2, 963 (1974).

371 I. S. Nicolaeva, N.S. Bogdanova, G.N. Pershin and A.V. Amur-Sanan: Farmak. Toks. 40, 82 (1977).

372 G.D. Diana, U.J. Salvador, E.S. Zalay, R.E. Johnson, J.C. Collins, D. Johnson, W. B. Hinshaw, R.R. Lorenz, W.H. Thielking and F. Pancic: J. Med. Chem. 20, 750, 757 (1977).

373 A.S. Galabov: Prog. Chemother. (Antibact. Antivir.) 2, 981 (1974).

374 A.S. Galabov, E.Kh. Velichkova and G.N. Vasilev: Chemotherapy 23, 81 (1977).

375 A.S. Galabov and E. Kh. Velichkova: Antimicrob. Ag. Chemother. 5, 1 (1974).

376 D. L. Swallow and R.A. Bucknall, unpublished results.

377 Note by T.J.M., Science 196, 1074 (1977).

378 K.D. Thiel, R. Kloecking and H. Bjoern: Zentbl. Bakt. Parasit. Infektionskr. 234, 159 (1976).

379 I. Beladi, R. Pusztai, I. Mucsi, M. Bakay and M. Gabor: Ann. N.Y. Acad. Sci. 284, 358 (1977).

380 W.S. Burnham, R.W. Sidwell, R. L. Tolman and M.G. Stout: J. Med. Chem. 15, 1075 (1972).

381 J.P. Dusza, H.L. Lindsay and S. Bernstein: US Patents 3,852,334, 3,855,276, 3,856,838; Chem. Abs. 82, 111841, 125173 (1975).

382 J.C. Chermann, F.C. Sinoussi and C. Jasmin: Biochem. biophys. Res. Commun. 65, 1229 (1975).

383 C. Jasmin, J.C. Chermann, M. Raynaud, G.H. Werner, N. Raynaud, F.C. Sinoussi and C. Boy-Loustau: Prog. Chemother. (Antibact. Antivir.) 2, 956 (1974).

384 G.H. Werner, C. Jasmin and J. C. Chermann: J. gen. Virol. 31, 59 (1976).

385 H.A. Tayim, A. H. Malakian: J. Pharm. Sci. 63, 1469 (1974).

386 B. Rosenberg, S.A. Mansy, L. L. van Camp and H.J. Peresie: German Pat. 2,445,418 (1974); Chem. Abs. 85, 28777 (1976).

387 C. Monti-Bragadin and B. Pani: G. ital. Chemioter. 21, 109 (1974).

388 L. N. Pankratova and G. S. Kharitonova: SU Pat. 484-220 (1976).

389 C. L. Purdy: US Pat. 4,025,621 (1977).

390 B.D. Korant, J.C. Kauer and B.E. Butterworth: Nature 248, 588 (1974).

391 B.D. Korant and B.E. Butterworth: J. Virol. 18, 298 (1976).

392 Y.J. Gordon, Y. Asher and Y. Becker: Antimicrob. Ag. Chemother. 8, 377 (1975).

393 J. Shlomai, Y. Asher, Y.J. Gordon, U. Olshevsky and Y. Becker: Virology 66, 330 (1975).

394 M. Bracha and M.J. Schlesinger: Virology 72, 272 (1976).

395 J. B. Schleicher and W.R. Roderick: German Pat. 2,208,787 (1971); Chem. Abs. 78, 11755 (1973).

396 N.L. Shipkowitz, R.R. Bower, R.N. Appell, C.W. Nordeen, L.R. Overby, W.R. Roderick, J. B. Schleicher and A. M. von Esch: Appl. Microbiol. 26, 264 (1973).

397 J.C. Mao, E.E. Robishaw and L.R. Overby: J. Virol. 15, 1281 (1975).

398 J.C. Mao and E. E. Robishaw: Biochemistry 14, 5475 (1975).

399 S. S. Leinbach, J.M. Reno, L.F. Lee, A.F. Isbell and J.A. Boezi: Biochemistry 15, 426 (1976).

400 L. R. Overby, R. G. Duff and J.C. Mao: Ann. N.Y. Acad. Sci. 284, 310 (1977).

401 R.W. Honess and D.H. Watson: J. Virol. 21, 584 (1977).

402 C. A. Alford and R.J. Whitley: J. infect. Dis. 133, suppl. A101 (1976).

403 B. A. Bopp, C. B. Estep and D. J. Anderson: Fed. Proc. 36, 939, Abstr. 3524 (1977). 
404 J.C. Overall, E. R. Kern and L.A. Glasgow: J. infect. Dis. 133, suppl. A237 (1976).

405 Y. Yajima, A. Tanaka and M. Nonoyama: Virology 71, 352 (1976).

406 D. Thorley-Lawson and J. L. Strominger: Nature 263, 332 (1976).

407 H. Barahona, M.D. Daniel, J.G. Bekesi, C.E.O. Fraser, N.W. King, R.D. Hunt, J.K. Ingalls and T.C. Jones: Proc. Soc. exp. Biol. Med. 154, 431 (1977).

408 J. Hay, S. M. Brown, A. T. Jamieson, F. J. Rixon, H. Moss and D. A. Dargan: J. Antimicrob. Chemother. 3, 63 (1977).

409 T.R. Herrin, J.S. Fairgrieve, R.R. Bower, N.L. Shipkowitz and J.C.H. Mao: J. Med. Chem. 20, 660 (1977).

410 H.J. Renis: Antimicrob. Ag. Chemother. 8, 194 (1975).

411 D.S. Hodes, T.J. Schnitzer, A.R. Kalica, E. Camargo and R. M. Chanock: Virology 63, 201 (1975).

412 C. Scholtissek, R. Rott and H.D. Klenk: Virology 63, 191 (1975).

413 F. Floch and G.H. Werner: Arch. Virol. 52, 169 (1976).

414 J. Hruskova, J. Jary, L. Danes, A. Jelinkova and M. Novak: Acta Virol. 19, 47 (1975).

415 S. Halperen: J. gen. Virol. 33, 389 (1976).

416 P. Gordon, B. Ronsen and D.P. Mucha: Fed. Proc. 34, 807 (1975).

417 P. Gordon: Am. Soc. Biol. Abstr. 74th Ann. Mtg., p. 265, Abstr. V386 (1974).

418 Scrip, 19 February 1977, p. 22.

419 P. Palese and R.W. Compans: J. gen. Virol. 33, 159 (1976).

420 J.L. Schulman and P. Palese: Proc. 9th Int. Congr. Chemother. 6, 215 (1975).

421 A.R. Schwartz, Y. Togo, R. B. Hornick, S. Tominaga and R. A. Gleckman: J. infect. Dis. 128,500 (1973).

422 T. W. Anderson, G. Suranyi and G. H. Beaton: Can. med. Ass. J. 111, 31 (1974).

423 J.L. Coulehan, K.S. Reisinger, K.D. Rogers and D.W. Bradley: New Engl. Med. J. 290, 6 (1974).

424 T.R. Karlowski, T.C. Chalmers, L.D. Frenkel, A.Z. Kapikian, T.L. Lewis and J.M. Lynch: J. Am. Med. Ass. 231, 1038 (1975).

425 F.A. Miller, G.J. Dixon, G. Arnett, J.R. Rice, W.A. Rightsel, F.M. Schabel, Jr., and J.W. McLean, Jr.: Appl. Microbiol. 16, 1489 (1968).

426 E. Nicolaides, H. de Wald, R. Westland, M. Lipnik and J. Posler: J. Med. Chem. 11, 74 (1968).

427 E. Norrby: Virology 44, 599 (1971).

428 E. Norrby and H. Sievertsson: Antimicrob. Ag. Chemother. 5, 426 (1974).

429 B.W.J. Mahy, N.D. Hastie and S.J. Armstrong: Proc. nat. Acad. Sci. USA 69, 1421 (1972).

430 H. Fujita: Antimicrob. Ag. Chemother. 3, 57 (1973).

431 S. Kanao, T. Toyoda, T. Suyama and S. Toyoshima: J. Pharm. Soc. Japan 95, 397 (1975).

432 A. Scioscia-Santoro, D. Cavallini, A.M. Degener, R. Perez-Bercoff and G. Rita: Experientia 33, 451 (1977).

433 R. Kant, K. Chandra, B. M. Gupta, K. B. Mathur, V. Kishore and M. M. Dhar: Indian J. Med. Res. 65, 314 (1977).

434 J.D. Williamson and L.C. Archard: J. gen. Virol. 30, 81 (1976).

435 V. Cavrini, A. Chiarini, L. Garuti, G. Giovanninetti and L. Franchi: Farmaco, Ed. sci. 31, 599 (1976).

436 A. N. Critselis, G. Rettura, A. Barbul and E. Seifter: Fed. Proc. 36, 1163 (1977).

437 P.W. Trown: Biochem. biophys. Res. Commun. 33, 402 (1968).

438 N. Neuss, L.D. Boeck, D.R. Brannon, J.C. Cline, D.C. de Long, M. Gorman, L.C. Huckstep, D. H. Lively, J. Mabe, M. M. Marsh, B. B. Molloy, R. Nagarajan, J.D. Nelson and W.M. Stark: Antimicrob. Ag. Chemother., p.213, 225 (1968).

439 K.C. Murdock: J. Med. Chem. 17, 827 (1974).

440 G. Lowe, A. Taylor and L.C. Vining: J. chem. Soc. (C), p. 1799 (1966).

441 D. Hauser, H.P. Weber and H.P. Sigg: Helv. chim. Acta 53, 1061 (1970).

442 D. Brewer, D.E. Hannah and A. Taylor: Can. J. Microbiol. 12, 1187 (1966). 
443 H. Minato, M. Matsumoto and T. Katayama: J. chem. Soc. (D), p.44 (1971).

444 D. Broadbent, H. G. Hemming and B. Hesp: German Pat. 2,346,389 (1972); Chem. Abs. 81,118531 (1974).

445 R. L. Devault and W. Rosenbrook: J. Antibiot. 26, 532 (1973).

446 R. A. Bucknall, H. Moores, J. Harrad and B. Hesp: Abstr. 9th Int. Cong. Chemother., Abstr. M336 (1975).

447 P.J. Curtis, D. Greatbanks, B. Hesp, A.F. Cameron and A. A. Freer: J. chem. Soc. Perkin Trans., p. 180 (1977).

448 K.H. Michel, M.O. Chaney, N.D. Jones, M. M. Hoehn and R. Nagarajan: J. Antibiot. 27, 57 (1974).

449 G. M. Strunz, M. Kakushima, M.A. Stillwell and C.J. Heissner: J. chem. Soc. Perkin Trans. 1, 2600 (1973).

450 H.C.J. Ottenheijm, G.P.C. Kerkhoff and J.W.H.A. Bijen: J. chem. Soc., Chem. Commun., p.768 (1975).

451 H.C.J. Ottenheijm, J.A. M. Hulshoff and R.J.F. Nivard: J. org. Chem. 40, 2147 (1975).

452 E. Heller, M. Argaman, H. Levy and N. Goldblum: Nature 222, 273 (1969).

453 J.H. Subak-Sharpe, M.C. Timbury and J.F. Williams: Nature 222, 341 (1969).

454 B. Moss, in: Selective Inhibitors of Viral Functions, p. 313. Chemical Rubber Co. Press, Cleveland, Ohio 1973.

455 L. G. Silvestri: Boll. Chim. Farm. 111, 329 (1972).

456 S. Riva and L. G. Silvestri: Ann. Rev. Microbiol. 26, 199 (1972).

457 G. Lancini, R. Cricchio and L. Thiry: J. Antibiot., Japan 24, 64 (1971).

458 T. Furukawa, S. Tanaka and S. A. Plotkin: J. gen. Virol. 28, 335 (1975).

459 T.E. O'Connor, C. D. Aldrich and V.S. Sethi: Ann. N.Y. Acad. Sci. 284, 544 (1977).

460 T.H. Matthews, M.K. Lawrence, C. D. Nair and D.A. J. Tyrrell: Lancet 2, 1387 (1976).

461 R.D. Dix and R.J. Courtney: Virology 70, 127 (1976).

462 N. Saito, F. Kitame, M. Kikuchi and N. Ishida: J. Antibiot., Japan 27, 206 (1974).

463 F. Suzuki, N. Saito and N. Ishida: Ann. N.Y. Acad. Sci. 284, 667 (1977).

464 R.A. Bucknall, H. Moores, R. Simms and B. Hesp: Antimicrob. Ag. Chemother. 4, 294 (1973).

465 J.C. Bode, U. Schmidt and H.K. Durr: Med. Klin. 72, 513 (1977).

466 G.A. Borel, J.L. Schellin and P. Mangenat: Z. Gastroent. 14, 24 (1976).

467 S. Tafur, J.D. Nelson, D.C. de Long and G.H. Svoboda: Lloydia 39, 261 (1976); Chem. Abs. 85, 139773 (1976).

468 M.T. Hatch, D. W. Ehresman, E.F. Deig and N.A. Vedros: J. Phycol. 13, 28 (1977).

469 S. Hotta, M. Kojima, M. Fujisaki, S. Uchida, H. Kuroda and C. Hamada: Nature 268, 733 (1977).

470 Y. Yamamura and K. W. Cochran: Mushroom Sci. 9, part 1, 495 (1976).

471 W. Lin, K. Oishi and K. Aida: Virology 78, 108 (1977). 